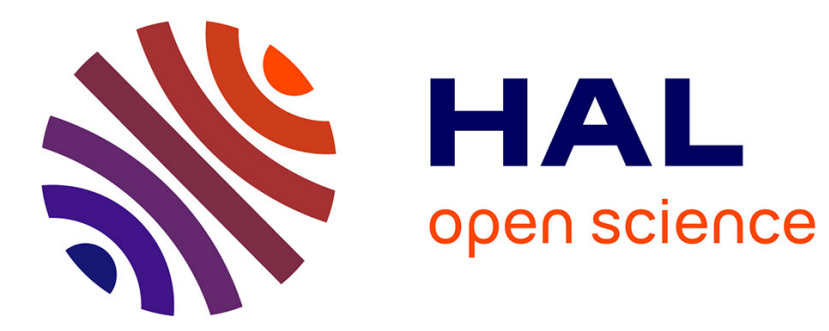

\title{
Knowledge systematisation, reconfiguration and the organisation of firms and industry: the case of design
}

Beatrice d'Ippolito, Marcela Miozzo, Consoli Davide

\section{To cite this version:}

Beatrice d'Ippolito, Marcela Miozzo, Consoli Davide. Knowledge systematisation, reconfiguration and the organisation of firms and industry: the case of design. 2014. hal-00962391

\section{HAL Id: hal-00962391 \\ http://hal.grenoble-em.com/hal-00962391}

Preprint submitted on 21 Mar 2014

HAL is a multi-disciplinary open access archive for the deposit and dissemination of scientific research documents, whether they are published or not. The documents may come from teaching and research institutions in France or abroad, or from public or private research centers.
L'archive ouverte pluridisciplinaire HAL, est destinée au dépôt et à la diffusion de documents scientifiques de niveau recherche, publiés ou non, émanant des établissements d'enseignement et de recherche français ou étrangers, des laboratoires publics ou privés. 


\title{
Knowledge systematisation, reconfiguration and the organisation of firms and industry: the case of design
}

\author{
Beatrice D'Ippolito \\ Grenoble Ecole de Management, France \\ beatrice.dippolito@grenoble-em.com \\ The York Management School, The University of York, United Kingdom \\ beatrice.dippolito@york.ac.uk \\ Marcela Miozzo \\ Manchester Business School, The University of Manchester, United Kingdom \\ marcela.miozzo@manchester.ac.uk \\ Davide Consoli \\ INGENIO (CSIC-UPV), Valencia, Spain \\ davide.consoli@ingenio.upv.es
}

\begin{abstract}
The paper explores two pathways that are crucial for making knowledge economically useful knowledge systematisation and knowledge reconfiguration - and analyses how their interplay enables the emergence of a new business function or activity. Knowledge systematisation is the abstraction and diffusion of operative principles to the effect of expanding to broader remits practices that had been initially conceived for a narrow purpose. Knowledge reconfiguration involves the conversion and formalisation of these novel practices within existing firm and industry organisation. Using the design activity as a lens, and drawing on primary and secondary interviews and archival data on the home furnishing sectors in Italy, our case study articulates the processes that facilitate the abstraction of general rules from novel practices and the changes that are necessary, both within firm and industry organisation, to foster their diffusion.
\end{abstract}

\section{Keywords}

Knowledge systematisation; knowledge reconfiguration; design; firm organisation; industry organisation; routines; capabilities; home furnishing. 


\section{Introduction}

What makes new knowledge economically useful? Many would argue that it is a spectrum of mechanisms that permits the recognition of opportunities and favours the implementation of new activities within the established mode of economic organisation. But knowledge implies a process, it is neither information nor facts, and the pathways through which it is rendered economically useful exhibit important peculiarities that depend on the context of development and use. Understanding the mechanisms that facilitate the progressive abstraction and formalisation of knowledge and practices into new organisational-level practices and organisational forms is important to appreciate the nature of those peculiarities, and their economic consequences. The present paper addresses these broad questions through the lens of the design activity, and seeks to uncover the processes that facilitate the translation of design know-how from being project-specific to becoming relevant to broader remits. Design can be prima facie regarded as a set of practices aimed at determining the formal qualities of products and defining how their functionalities will be delivered to users (Utterback et al., 2006). The broad range of organisations and sub-sectors design impinges on and the heterogeneity of expertise, skills, and techniques that it entails make design an appropriate context for our empirical investigation.

The paper analyses two pathways that are crucial for making design knowledge economically relevant. The first is knowledge systematisation, that is, the abstraction and diffusion of operative principles to the effect of expanding the remit of practices that had been initially conceived for a narrow purpose (Rosenberg, 1976a). The second is knowledge reconfiguration, involving the conversion and formalisation of these novel practices within firm and industry. This involves the development of new routines or practices and relations between routines as a result of new knowledge. Our articulation of these two processes and of their interdependences fills two gaps in the area of innovation studies. On the one hand, while the concept that knowledge evolves as a by-product of practice is widely accepted, the institutional mechanisms that permit the diffusion of practical know-how are still understudied (Baumol, 2005; Vona and Consoli, 2011). For many industries, future viability depends not on today's technology but on the contribution of tomorrow's trained professionals. This raises cogent questions concerning the effectiveness of the systems that are expected to ensure the replenishment of the skill base, such as: how is new professional know-how formalised for wide use? On the other hand, while the processes of technological convergence, specialisation, and vertical (dis)integration have been explored in the past 
(Rosenberg, 1963; Sturgeon, 2002; Miozzo and Grimshaw, 2011), the study of how the formalisation of novel know-how affects firm boundaries, the development of new types of firms, new routines, or even the formation of new industries, is still in its infancy. In short: how do new practices become progressively formalised within organisations and are aligned with (and, in turn, change) the existing 'ways of doing things'? We are still short of understanding how both these processes work, how they affect (and change) economic organisation, and under what circumstances.

The case study presented here draws on different sets of primary and secondary data sources on the Italian home furnishing sectors and contributes to existing scholarly work by affording a number of insights. First, it calls attention to the process of capability development both at firm and industry level. This dual lens resonates with the extended remit of design, which involves not only form and function of products but also modes of production and delivery, as well as product meanings (or symbolic value) (Walsh, 1996). A second insight of this work is an appreciation of the nuances of problem-solving in design activities, partly drawing on art and partly on engineering and, to a lesser degree, science. Design is a bridge between the craftsmanship required to master materials and the social sensibility necessary to capture and convey meanings to society. The chief preoccupations of professional designers revolve around where objects are placed, what they communicate and how. Clearly, their ability to capture and convey meanings rests on a distinctive feedback system that links the domain of practice with the organisation of production. Yet another contribution of the paper is a novel set of insights on how new practices, some of which are easily codified and some of which remain largely tacit, are accommodated within (and change) existing firm and industry organisation.

The remainder of the paper is structured as follows. Section 2 lays out the conceptual framework to understand how a focus on knowledge systematisation and reconfiguration can help explore the processes of emergence of a new business activity or function. Section 3 discusses the research methodology. Section 4 presents the main findings on knowledge systematisation and reconfiguration in the context of design, and the organisational consequences at firm and industry level. After the discussion in Section 5, the last section concludes and summarises. 


\section{Knowledge systematisation and knowledge reconfiguration}

Types of knowledge differ from one another not only in relation to the content but also in the ways in which they generate opportunities. By and large these differences can be ascribed to the peculiar combination of circumstances that underlie each domain of knowledge generation and use. Here we consider two mechanisms that facilitate the translation of innovative, at times disruptive, knowledge inputs into economically viable courses of action: (i) the abstraction and diffusion of useful knowledge stemming from novel practices, namely, knowledge systematisation; and (ii) the development of new routines or practices and relations between routines as a result of new knowledge, namely, knowledge reconfiguration.

\subsection{Knowledge systematisation}

Let us begin by operationalising useful knowledge, that is, "knowledge that deals with natural phenomena that potentially lend themselves to manipulation, such as artefacts, materials, energy, and living beings" (Mokyr, 2002:3). Useful knowledge is the practical know-how that is needed to make things work. Scholarly research articulates the latter as an evolutionary construct, as the process through which initially tacit and dispersed notions are progressively selected and become embedded in tangible outcomes such as novel techniques, rules or practices (David, 1975; Constant II, 1980; Basalla, 1988; Cragg, 1989; Vincenti, 1990; Ziman, 2000; Nelson, 2003). The breadth of perspectives on the question "what is useful knowledge?" stands in contrast with the lack of contributions on a particular aspect: what institutional processes facilitate the consolidation of specific forms of know-how into broadly applicable instructions? That is, how does knowledge become economically 'useful'?

The work of Nathan Rosenberg stands out as a pioneering attempt towards articulating these issues beyond the abstract evolutionary metaphor. His early work (Rosenberg, 1976a) deals with crucial questions concerning knowledge diversification, division of labour, and the mechanisms that ensure coherence across increasingly specialised production activities. He argued that the viability of mass production systems depends on stable systems of rules, or standardised instructions, based on the systematic observation of how materials react to certain treatments in large-scale operations. This type of know-how, Rosenberg insisted, stems not from basic scientific areas like chemistry or physics but is rather a by-product of cumulative practice on the part of engineers and technicians who run experiments in different contexts. While the point that knowledge evolves as a by-product of practice has been widely accepted by innovation scholars inspired by Rosenberg, the institutional mechanisms that 
permit the formalisation and diffusion of practical know-how is still arguably underdeveloped (Vona and Consoli, 2011). In later work, Rosenberg (1998a, b) returned to this theme by calling attention to 'roundabout' areas of specialisation acting as incubators for novel practices. One among them is chemical engineering, which emerged in the 1920s out of progressive interpenetration of two established but traditionally separate realms - chemistry and engineering. Despite being initially conceived to meet the specific needs of the petroleum sector, chemical engineering has acquired increasingly universal character to become the main feedstock for a broad range of industries. Put otherwise, this branch of engineering has generated an inter-temporal spillover that binds together existing know-how with new knowledge: "a new blueprint today spills over to lower the cost of future blueprints" (Rosenberg, 1998a:168).

The study by Vincenti (1990) on the history of the aeronautical industry offers further insights on the role of practical forms of know-how. Focusing on the relationship between experiential know-how and scientific knowledge in the collection of instructions for aircraft control, he described the institutionalisation of operative standards for airplane control culminating in a newly created teaching module, control-volume analysis. The latter encompasses practices and specifications for engineers to apply "the physical laws governing mass, momentum, energy and (when needed) entropy" (Vincenti, 1990:113). This is an example of how recursive learning in practice contributes to the definition of operative criteria, thus consolidating the notion of engineering epistemology as an autonomous body of knowledge based on problem-solving heuristics rather than on science. Building on Vincenti's contribution, Nightingale (2000) elaborated a framework to articulate how technologyspecific knowledge generates interdependent problem-solving tasks. In a nutshell, innovation processes depend on the physical characteristics of the product and organisation of firms and industries by generating meaningful product-process-organisation relationships. The history of windmill-generated electricity resonates with this and provides further relevant evidence. Danish meteorologist Poul la Cour is credited with having built one of the first 'direct current' wind turbines, the prototype of the modern three-blade wind turbine design, as a result of recursive practice (Hau, 2000; Nielsen, 2010). To be sure, he pursued practical goals, namely to enable farmers to exploit wind power and to train a new generation of windmill designers (Jones and Bouamane, 2011). Indeed among his most brilliant students was Johannes Juul, a farm electrician with little formal education who conceived and implemented the practice of connecting several turbines located in a small piece of land to enhance overall energy 
collection and distribution - the basic foundation of modern wind farms (Heymann, 1998; Nielsen, 2010). Coherent with the style of his master la Cour, Juul's turbine design emerged as a result of gradual up-scaling guided by trial-and-error.

Taken together, these examples offer illustrative evidence of an important process: the systematisation of knowledge, that is, the formalisation, articulation, and verification of learned practices into a synthetic set of rules and instructions (Yoshikawa, 1993). This definition accounts also for the tacit component characterising knowledge-intensive activities, which is mostly neglected when focusing exclusively on codification processes. As highlighted by Balconi (2002), when a task is automated (i.e., its knowledge base is systematised) a different skills set may be needed compared to when the same task is undertaken manually. Furthermore, knowledge systematisation encompasses both qualitative and quantitative dynamics. The process typically begins with a meta-model, that is, a symbolic representation of fundamental principles and the relationships across the relevant physical units. This initial 'figuring out' offers a rough guide towards the parameterisation of physical characteristics of products and processes. Importantly, the meta-model remains open to modifications stimulated by experimental testing that either corroborates or refutes the basic principles, or their relation. The principles generated by means of trial-and-error, that is, the emergence of practices through learning-by-doing, are gleaned from experiential observations and evolve into independent epistemic domains such as engineering (Vona and Consoli, 2011; Rosenberg and Steinmueller, 2013). We suggest that these concepts can elucidate the analysis of the pathways through which new sets of rules and instructions emerge and expand their remit beyond the purpose for which they were originally conceived (Rosenberg, 1976b).

All the foregoing examples draw attention to important conceptual aspects too. In particular, they speak to the mutual influence between practical know-how and the development of scientific knowledge and the interplay between pathways for learning-by-doing and knowledge articulation. A parallel debate within the neo-institutionalist tradition emphasises, that the establishment and further development of a new activity are the result of distributed adaptive behaviour across competence domains (Tolbert and Zucker, 1996). Arguably, however, these works on the transition from pre-institutionalisation to institutionalisation overlook the role of practices. These have been subsequently developed in greater detail by work underscoring the importance of bottom-up change. Greenwood et al. (2002) and Smets et al. (2012) in particular show how field-level institutional change emerges from the 
mundane activities of practitioners, becomes institutionalised at the level of the organisation, and instigates further institutional change in the field. ${ }^{1}$

Building on these conceptual tracks, this paper aims at identifying how formalisation, and not necessarily codification, of knowledge takes place through abstraction, that is, exploring the mechanisms through which technology-specific knowledge generates interdependent problem-solving tasks, thus highlighting the impact that bottom-up dynamics of change can have on professional practice.

\subsection{Knowledge reconfiguration and firm and industry organisation}

Not only are firms generators and users of systematised knowledge, but also the processes of knowledge abstraction and diffusion described above can trigger the development of new routines and the reconfiguration of existing ones, and bring long-term changes in the knowledge bases of firms, and in firm and industry organisation. ${ }^{2}$ Indeed, the processes described above can create conditions under which the efforts of certain forms of organisation (markets, vertical integration, alliances, etc.) may be superior for exploiting the new expertise and skills.

In the case of mass production, at the root of Henry Ford's breakthroughs stood the systematisation of knowledge from other industries that enabled the mastering of the two key principles of mass production: interchangeability of parts and flow. Indeed, Ford adopted practices developed nearly a century earlier at the Springfield Armory in Massachusetts for the production of standardised, interchangeable parts. Interchangeability of parts was achieved through careful adherence to a rational jig and fixture system and model-based system of gauging (Best, 2001). His factory also relied on practices developed in grain conveying machines, breweries, foundries, bicycle production, canning and meat-packing to develop the principle of flow. Flow involved laying out the plant to maximise throughput efficiency, working on bottlenecks and driving down standardised cycle times, developing the rudiments of process and product engineering (Hounshell, 1984; Best, 2001). Supported by infrastructural developments in transportation and communication, and taking advantage of cheap and flexible energy, large firms pursued economies of speed and productivity increases,

\footnotetext{
${ }^{1}$ We are grateful to an anonymous referee for drawing our attention to this.

${ }^{2}$ Routines are hereby defined as the basic components of organisational behaviour and repositories of organisational capabilities (Nelson and Winter, 1982); however they can also manifest in either cognitive or behavioural patterns which include both explicit and tacit aspects from experience accumulation (Cohen and Bacdayan, 1994; Cohen, 2007).
} 
which were permitted by interchangeability and flow (Miozzo and Walsh, 2006). The new imperative to maximise utilisation of plant capacity and orchestrate increasingly diverse sources of supply and sales also had significant organisational implications. For one, it gave rise to the expansion of managerial structures and to the large, hierarchically organised, vertically-integrated firms (Chandler, 1977). As differentiated products superseded markets for homogenous products, the predominant firm structure changed from the unitary to the multidivisional form. Concomitantly, and facilitated by federal funding of education of scientists and engineers in the USA, the research and development (R\&D) function was internalised in large firms (Noble, 1977). The establishment of a new form of firm organisation and new business functions was evidence of transformations brought by knowledge systematisation and reconfiguration. In addition, Ford's openness spurred the rapid diffusion of production technology and organisation principles that he contributed to shape and, within a decade, several firms producing household appliances such as vacuum cleaners and radios were organised according to those canons (Hounshell, 1984). Clearly the new operative principles brought transformations within individual firms, leading to the new large vertically-integrated firm, but they also spread throughout entire industries.

Another instance of the far-reaching effects of knowledge systematisation and reconfiguration is the development of the US machine tool industry which emerged from machine shops linked to New England textile mills in the 1820s and 1830s. Rosenberg (1963, 1976a) shows how, with the growing volume of manufacturing output, increased vertical disintegration from single industries was accompanied by technological convergence of larger groups of industries. In the specialised machine tool industry, new skills and techniques were developed or perfected in response to the demands of a broad range of client firms. Once these skills and techniques were acquired, the machine tool industry became the main 'transmission centre' for their transfer to the entire machine-using sector, thus generating substantial external economies. As mentioned above, the firearm industry was instrumental in the development of tools and accessories upon which the large-scale production of precision metal parts was dependent, such as jigs (originally employed for drilling and hand-filing), fixtures, taps and gauges, and the systematic development of die-forging techniques (Rosenberg, 1963). This bears testimony to emergent interdependence across diverse industries, hinging upon a limited number of problem-solving processes that eventually became "the specialised function of a well-organised industry" (Rosenberg, 1963:443). We see here how the knowledge systematisation and reconfiguration behind the establishment of general-problem solving 
processes led to changes in industry organisation in the form of the development of a new specialised industry.

A more recent example is the move to modular production networks in electronics. Advances in modularity and information and communication technologies shift the balance towards greater disintegration of product design and manufacture, especially through the acquisition of outsourced manufacturing plants from electronics firms and the consolidation and international presence of global first-tier suppliers of autoparts (Sturgeon, 2002). The availability of codified inter-firm links and the development of generic manufacturing capacity by turnkey suppliers triggered external economies of scale in modular production networks (Baldwin and Clark, 2000; Sturgeon, 2002). These suppliers (contract manufacturers) coordinate the flow of inputs and outputs through their factories and invest in expensive but generic equipment to cater for a large customer base, accruing economies of speed despite market uncertainty faced by any single brand name firm (Sturgeon, 2002). Similarly, the development of IT services function and independent large suppliers of IT services emerged in response to the common challenge of firms in all industries to manage information flows, technological developments enabling the integration of previously heterogeneous and incompatible proprietary computer platforms and hardware components, as well as standardisation of interfaces between applications, and combined institutional and organisational changes (Miozzo and Grimshaw, 2011). In all these cases, knowledge systematisation and reconfiguration, arguably relying more on science and less on experiential content, created the conditions for the outsourcing of tasks previously carried in-house and the development of new relationships with suppliers, including contract manufacturers or IT services firms, to the effect of expanding the range of operations in different industries. Knowledge reconfiguration can thus be regarded as involving both the development of new routines and the reconfiguration of existing ones, thus resulting in novel, formalised knowhow. These processes stimulate changes in firm boundaries, the development of new types of firms, new business activities or functions and new industries altogether. The examples above bring to light how systematisation and reconfiguration affect the 'ecosystem' of competencies and operative rules triggering transformations of the prevailing knowledge base. Taken together, knowledge systematisation and knowledge reconfiguration are useful conceptual categories to elucidate the process by which novel, initially disconnected, practices trigger the development of particular forms of know-how and expertise that consolidate their status in the extant structure. 
The remainder of the paper elaborates further these conceptual categories through a case study on design, which gives the possibility to illustrate that potentially valuable experimental activities are strictly interwoven with intangible aspects such as tastes and dominant culture, thus influencing the setting and contributing to the development of new types of firms, new routines, or even the formation of new industries.

\section{A case study on design}

The goal of this paper is the analysis of instituted processes that make knowledge economically useful. In particular, we aim at identifying how this takes place through the abstraction and formalisation processes described above, and the related changes in the organisation of firms and industry. We do so by studying the case of design. While in prima facie design can be perceived as a set of practices aimed at meeting functional or aesthetic considerations, the present study shows that by spurring multiple associations across functionalities its remit often extends beyond the creation or modification of physical objects. Our chief interest is the process by which some design practices are developed and transferred to other broader dimensions.

\subsection{The context}

Design has been a central part of firms' strategies for as long as the physical properties of materials have demanded the implementation of dedicated routines to achieve desired product specifications. Rooted etymologically in 'making of a drawing', design encapsulates domains as diverse as creativity, organisation of production, and articulation of engineering principles. The paucity of statistical data about design, both as activity and as sector, is perhaps the strongest testimony to the persistent lack of agreement as to where its boundaries lie (Walsh, $1996)^{3}$ or to its slippery definition (Love, 2002). Nevertheless, the 'hidden role' of product design pervades the literature on firm innovative performance connected to strategic, financial (Roy and Wield, 1986; Walsh et al., 1988; Potter et al., 1991; Walsh et al., 1992), economic, sociological and managerial (Rothwell and Gardiner, 1983; Walsh and Roy, 1983) aspects. These studies reaffirm the centrality of product design but also point out that coalescing

\footnotetext{
${ }^{3}$ Even in a NACE context, one would struggle to find design-related activities in the same category. For instance, "Design and assembly of industrial continuous process control systems" is classified within Class 33.30 "Manufacture of industrial process control equipment"; the activity Consulting architectural activities: building design and drafting, etc." within Class 74.20 "Architectural and engineering activities and related technical consultancy"; and the activity "Fashion design related to textiles, wearing apparel, shows, jewellery, furniture and other interior decoration and other fashion goods as well as other personal household goods" within Class 74.84 "Other business activities n.e.c." (NACE, 2008).
} 
design expertise with innovation strategy is not straightforward. More recent work on design management explores how design activities are practically integrated with innovation and strategy-building (Gemser and Leenders, 2001; Hertenstein et al., 2005; Perks et al., 2005). Another stream of research draws attention to how designers become key actors for product innovation and strategic renewal (Lojacono and Zaccai, 2004; Ravasi and Lojacono, 2005), new product or service development (Swink, 2000; Candi, 2010), or for marketing (Veryzer, 2005; Luchs and Swan, 2011). In spite of these efforts, Chiva and Alegre (2009) argue that research on the contribution of design to innovation performance has to be further explored and, as D'Ippolito's (2014) review of the design literature suggests, it is also strategically relevant to learn how design-related skills and competencies are combined with firms' existing competencies.

For the purpose of this paper, we understand design as a set of routines aimed at meeting functional or aesthetic specifications. These rely on properties of raw materials and on scientific principles learned via formal and informal processes. Design is operationalised through steps, namely, problem identification, problem categorisation, and problem solving (March and Smith, 1995; Hevner et al., 2004). Each of these generates feedback on which designers act upon by trial-and-error iterations around emerging configurations. Design routines confer coherence to disperse elements of a problem that, just like raw materials, do not yield a clear structure in the absence of an intentional architecture. In an attempt to consider the multifaceted nature of design involving both analytical and symbolic knowledge (Verganti, 2008) but also as a strategic tool (Rothwell and Gardiner, 1983; Walsh, 1996; von Stamm, 2008), we synthesise the key aspects below:

- Design is a set of activities or business function that relies on a diverse knowledge base and encompasses both analytical (engineering) and symbolic (meanings) knowledge;

- It is a process that draws significantly on creativity, posing serious challenge to formalisation; and

- It is also a service that provides input to the innovation strategy of the firm, both within and across organisational boundaries, i.e., both in relation to the specialisation of individual firms and the industrial domain within which they operate.

Only a few contributions from the specialised design literature hint at knowledge systematisation or reconfiguration. Kotler and Rath (1984) suggest that product design is a strategic tool for optimising consumer satisfaction and company profitability by creating 
performance, form, durability, and value in connection with products, environments, information, and identities. They also call attention to the importance of training general managers, marketing staff, and engineers to understand design, and, in turn, to encourage designers to be aware of and learn about the role and function of these members of staff (Kotler and Rath, 1984). Dumas and Whitfield (1989) coincide with the former view and add that, since it is unlikely that those involved recognise the activities of all participants in the design process, it is also unlikely that a structure (that is, a business function in the conventional sense) can develop in such a way that enables effective cooperation between these professionals. This challenges the process of coalescing design expertise with firm innovation strategy. More recently, Verganti (2003) appraised the central role of industrial designers within design-driven organisations. In particular, he points to three key ingredients to competitive advantage: the network of relationships of designers with brokers of languages; channels to access this knowledge; and internal coordination to support the integration of these inputs (Verganti, 2003).

Scholarly research has so far explored how design knowledge matches firms' structure (Perks et al., 2005; von Stamm, 2008) or strategy-making dynamics (Ravasi and Lojacono, 2005; Filippetti, 2010). In particular von Stamm (2008) examines the expansion of pathways for the practical implementation of design within the matrix of firms' activities. Yet, as argued earlier, innovation depends on how these new skills and techniques are organised and coordinated as new knowledge is generated, new practices emerge, new activities or functions are developed, and new types of firms or industries evolve. This implies articulating the relationship between the introduction of design practices and the systematisation and reconfiguration of the specialised knowledge. These matters have been rarely discussed in the context of design studies. A recent historical study by Lees-Maffei (2008) recounts the role of professional organisations, the definition of standards, and the institution of clear educational routes in design in the UK and the USA. The original conception of design schools was that of an 'experimental collective' wherein individual skills were nurtured and channelled. Over time, however, growing concerns over financial viability forced the evolution of design training towards a more standardised curriculum (Findeli, 1991; Lesko, 1996) responding to the cost-cutting imperatives of large-scale production. This, however, creates conflicts as, for example, is argued by Findeli (1991), who states that design education and industrial practice have different and irreconcilable time spans and values. Within the innovation literature, some scholars have illustrated how routines or capabilities emerge from either formal or informal 
activities. There can encompass cases in which capabilities develop through complex chains of both intentional and emergent activities (Salvato, 2009) or where local knowledge is translated into routines, for instance, through prototyping activities (D'Adderio, 2008). In this paper we consider dynamics not so much within but between organisations and between organisations and the wider institutional domain.

\subsection{Research design}

The present study focuses on the home furnishing sectors, which comprise wooden furniture, lighting, kitchen furniture, living room furniture, bathroom furniture, office furniture, and contract design. We rely on four sets of primary and secondary data sources to explore the connection between the relevant technological, organisational and institutional advancements of these sectors. In line with the exploratory nature of the research, data collection followed a loose timeline through which there has been some overlap with data analysis, a common feature of theory building via case studies (Eisenhardt, 1989). This approach enriches the validity of data and facilitates the adjustment of objectives that are pre-established in a deductive way with elements that are identified later on, according to an inductive logic. As a first step, we inspected books and design catalogues from the Faculty of Architecture and Industrial Design library of the Polytechnic of Milan to gather information on: (i) the technological changes of the sectors and the advancement of the relevant knowledge bases, (ii) the mission and objectives of the relevant actors and institutions, and (iii) the birth of a new (institutionalised) domain of activities. These secondary sources cover a timeframe of 90 years (1920-2010).

Secondly, we analysed a set of publicly available interviews with leading experts on Italian design - the list of interviewees (thirty-seven in total) is reported in Appendix Table 1. These interviews were conducted during the early 1990s by a group of Italian designers and the transcripts have been both posted in a blog of the $\mathrm{RAI}^{4}$ and published as an Editorial of the Domus Magazine in 1996.

\footnotetext{
${ }^{4}$ RAI Radiotelevisione Italiana S.p.A. (known as Radio Audizioni Italiane since 1954) is the Italian state owned public service broadcaster controlled by the Ministry of Economy and Finance. Rai Educational is a section within the RAI website that is dedicated to delve deeply into selected themes. One of these regards the Italian design and contains a list of interviews that have been conducted with designers and other experts who are recognised worldwide because of the active role they have played within the design scene in Italy. The interviews are available at: www.educational.rai.it/lezionididesign/designers/index.htm (first access date: 17/12/2009).
} 
Thirdly, we examined the curricula for professional training in major schools of industrial design for the academic year 2010/11. This included the curricula of two top design schools in Italy, the European Institute of Design and the Faculty of Industrial Design at Polytechnic of Milan. ${ }^{5}$ We also consulted materials on site and had informal discussions with academic staff at the School of Arts at Manchester Metropolitan University in the UK.

Fourthly, we carried out fourteen semi-structured interviews with chief executives and senior managers of different departments (i.e., product development, R\&D, marketing, and art director) in a set of furniture manufacturing firms in Italy. These were selected from the pool of exhibitors at the Salone Internazionale del Mobile 2010, based on the experience of these firms with design and a history of frequent new product development, all elements that have contributed to their international reputation. ${ }^{6}$ Indeed, we selected firms that are well known for undertaking design activities on a regular basis. A range of firms was selected to ensure diversity in the investigation of the processes of (design) knowledge creation and transmission within and beyond organisational boundaries. We chose firms that develop new products on a yearly basis (the average product life cycle within the sector ranges between 1.5 and 3 years). A number of additional criteria were used for the selection: size and location, that is, a balanced distribution of size (micro, small, medium and large size) and geographical areas; openness, that is, level of imports and exports as expressing the position of the firm within both the home and foreign markets; innovation type, that is, firms introducing mainly product innovations were considered (a different focus would imply a different set of theoretical and methodological choices); and different ways of managing design expertise, that is, the sample included companies that have in-house design expertise, subcontracted design, or a combination of the two (see list of sampled firms in Table 1). We believe that this set of criteria prevents biased findings. The adoption of multiple case studies (as opposed to single case study research) has often been criticised because of the likely lack of depth (Dyer and Wilkins, 1991). In the context of this research, however, selecting more than one case was appropriate to account for differences between cases and gain additional insights to develop new knowledge.

\footnotetext{
${ }^{5}$ Source: http://www.universando.com/blog/elenco-migliori-istituti-di-design-in-italia/ (access date: 30/09/2011).

${ }^{6}$ It is worth mentioning that in a design-dominated context reputation is built not only by increasing a firm's visibility but also by establishing long-term collaborations with renowned designers. This draws attention to the (intangible) prestige elements of design, and it confirms the difficulty in disentangling its contribution to innovation.
} 
Table 1 about here

Interviewees included senior managers (mostly directors) of the $\mathrm{R} \& \mathrm{D}$, design and product development departments, and the founder of the firm. Clearly, we had to adapt our expectations to each and every case (see details of the interviews in Appendix Table 2).

Written consent from interviewees was gathered and stored as a physical dataset. Interviews were semi-structured, and uncovered different aspects of new product development. The icebreaking question was "what are the roots of your design traditions?", which meant that all the respondents started the conversation with an historical excursus of their firm's establishment and referred, from time to time, to cases of product successes or failures. The rest of the questions referred to: the new product development (NPD) process, the skills and competencies acquired or developed, creativity, and project working (see copy of the interview guide in Appendix Exhibit 1). Through the primary interviews we captured the adaptation of firms' knowledge bases, the development and deployment of specialised competencies, and the emergence of new practices, roles, and organisations at micro and meso level.

The case study methodology is justified by the lack of theoretical contributions on the emergence of design as a new business activity or function. Furthermore, this methodology allows us to exploit the advantage of in-depth focus on selected cases while maintaining contextual richness (Yin, 2009). Our focus on home furnishing sectors as opposed to all the sectors in which design knowledge finds application entails the benefit of dealing with a domain that is economically and technologically homogenous (Chiva and Alegre, 2007). Indeed, from both a theoretical and a methodological point of view it would be incoherent to treat innovation in materials originating within a furniture firm akin to, for example, innovation in fabrics within a fashion design studio because the knowledge bases are different and it would be difficult to develop new conceptual insights.

\subsection{Data analysis}

The method of data analysis was strictly intertwined with how the findings were reported. Among the available alternatives, we selected the theory building structure (Gray, 2004). The aim was to build a theory of the processes of systematisation and reconfiguration of knowledge in the emergence of design, from which research questions and propositions 
emerge and evolve, thereby strengthening the exploratory purpose of the case study exercise (Eisenhardt and Graebner, 2007).

Data analysis proceeded in two stages. In the first we followed a narrative approach (Langley, 1999) to identify key events in the emergence and developments of systematisation and reconfiguration mechanisms of design knowledge. Events were defined as those instances of learning that enrich the innovative ability of the actor(s) involved, either at the individual or group level, and were considered 'key' when they generated a mutation of the extant organisational arrangements (for instance, acquisition of new skills). Since our ultimate scope was to learn about the mechanisms of knowledge systematisation and reconfiguration, we focused on events that were observed to be at root of critical learning and to have spurred routinisation of design activities. In the second stage, we compared and contrasted the analysis of field data that elucidate interrelated features of knowledge systematisation and reconfiguration, and the inductive perspective in data coding was compared and contrasted with explanations about patterns of firm and industry organisation established in the literature (Suddaby, 2006). We note the importance of being open-minded and not assuming any causal relationship between the constructs (van der Aa and Elfring, 2002).

Templates were used to conduct data analysis. Rather than a single, clearly defined technique, template building was centred on a varied, but related, group of techniques aimed at organising and analysing textual data (King, 2004). Both theory and pre-established research objectives constituted the basis upon which the initial template was developed (Miles and Huberman, 1994). By alternating between inductive and deductive techniques, the template was revised and updated. To start with, secondary data were analysed based on a preliminary set of codes to (i) identify the patterns of development of the home furnishings design sectors, and (ii) understand how design know-how has become systematised and reconfigured (i.e., what has allowed the abstraction and diffusion along with new development of design knowledge). We found that design was being incorporated into the innovation strategy of the firm by generating a body of knowledge difficult to formalise, which also fostered the establishment of interactions between formerly unrelated professionals, such as prototypers, designers, art directors, and materials experts. Moreover, it was possible to observe some coherence between the evolution of design and the development of firm routines (such as the establishment of prototyping workshops), as well as changes at industry level (for example, partnership with education institutions, or collaborations with trade associations). These findings draw attention to additional sub-questions, namely: how does design know-how 
emerge and develop within firms? What is the influence that institutions play on the evolution of design know-how? How does the increased formalisation of design knowledge (e.g., new education degrees) shape the formation of design skills and techniques at firm level? Driven by extant literature emphasising the importance of feedback and learning loops in the design process (Vincenti, 1990), we focused on the interplay between knowledge formalisation and firms' knowledge bases on one hand, and specialisation and division of labour on the other. Thus, in a second stage of data analysis, we addressed these questions by enriching the issues that would be discussed in interviews. Appendix Table 3 includes a list of these issues as well as the underpinning theoretical justification and exemplary quotes.

\section{Findings}

This section presents key findings of the empirical study. Table 2 can be used as a guide for the most representative quotes in support of our findings.

Table 2 about here

\subsection{Key technological, organisational and institutional changes in the emergence of design}

The home furnishing sectors in Italy experienced little technical advance until the midtwentieth century. ${ }^{7}$ In the late 1940 s, the development of tubular steel, bent plywood, and plastics allowed furniture designers to begin to reap the potential of new materials, and explore new forms for the modern age. Alberto Alessi explained the advantages of new materials, "the experimental activities with plastics allow us to decrease substantially the average age of our consumers, and designers can come up with more diversified forms" ([a] in Table 2). As a result of such changes, firms adopted a more systematic approach to the development and management of design knowledge. Indeed, firms' production department and product developers started to collaborate with small workshops to balance efficiency and creativity via experimentation with the challenges posed by new materials or technologies. Also, their staff started attending conferences and events with this same aim: "sometimes it is curiosity... sometimes we proactively participate in events not necessarily connected with the

\footnotetext{
${ }^{7}$ Iron, in its cast state, and, later, in the form of steel, was the material of the day. The French Art Deco was taking advantage of those new materials for decorative purposes (e.g., balconies and metro stations), the USA had a more functional approach by developing the all-steel car body, an innovation which was made possible by using the new steel-stamping machinery (Falabrino, 2004).
} 
furniture sector". ${ }^{8}$ In spite of growing interest, designers and manufacturers were still short of experience with certain materials and the associated production methods. Ernesto Gismondi a leading furniture manufacturer - recounts the difficulty of both technical and economic nature attached to the use of plastics, "technical because the moulds are very complex, made up of alloy steel, and have to be built in order to withstand up to two thousand tons of pressure; and economic because in the late 1960s they cost us hundreds of millions of lire" ([c] in Table 2).

As the poor aging process of plastics became apparent, the simple lines of the designs made of wood, glass, and metal by the masters of their day were again being appreciated in the 1950s and 1960s (Wulfing, 2003). Nevertheless, the deepening of research on artificial materials and new treatment of plastics, combined with general trends of developments in information and communication technologies (ICTs) and globalisation, led to increased knowledge sharing across sectors ([d] in Table 2). The use of ICTs in design fostered abstraction and formalisation of knowledge into a set of rules and instructions that increased exponentially their applicability. For instance, "in the wooden furniture sector, even those pieces with traditional shapes, which fall in the cabinet-making tradition, are nowadays manufactured by numerically controlled machines, and the artisans deal mainly with the finishing touches". 9 Moreover the discovery of new ways to treat materials allowed furniture makers to use plastics in more traditional pieces of furniture, such as cabinets or tables, but also in more particular objects such as different types of chairs ([e] in Table 2). The introduction of the 'plastic procedure' (as defined by a designer interviewed) paved the way for the rationalisation of production, with, for example, the production of a chair requiring one piece of material instead of three or four, as well as to aesthetic improvements. A key challenge during post-war reconstruction was efficient production of artefacts for everyday life. Prefabricated elements such as the 1970 Compasso d'Oro winner "Sistema P 63" by C. Conte and L. Fiori for Pasotti allowed for quick assembly, easy installation, and space-saving in most construction or domestic interior spaces (Wulfing, 2003:44). Along with the new trend of making household products modular, manufacturers started to explore more systematically options for seating and, as a result, furniture production grew by $60 \%$ between 1970 and 1974 (Raimondi, 1990).

\footnotetext{
${ }^{8}$ Interview with Molteni\&C. See [b] in Table 2 for additional empirical evidence.

${ }^{9}$ Interview with Baroni Daniele.
} 
Throughout this process, the institutional settings underwent important transformation. Four new organisations played a key role in the advancement and promotion of Italian design and fostered knowledge sharing among practitioners. The first was the Triennial, an international exhibition created in the 1920s with the purpose of showcasing the decorative arts and taking place every three years. The construction of a suburb in the metropolitan area of Milan under the direction of architect Piero Bottoni became the space for experimenting with architecture and raised interest on themes that would be debated in future exhibitions. ${ }^{10}$ Indeed, the Triennials were events for encouraging ideas exchange and for debating critically themes like town planning, social architecture, and high-quality industrial production. This approach was resumed in 1947 when different curators proposed to tackle the post-war recovery more systematically. As a result, the Triennial Foundation became an established locus for the diffusion and exchange of design culture and a focal point for the (institutionalised) emergence of design as a new business activity. The second was the Compasso d'Oro, an award for designers and manufacturers who achieve a synthesis of form and function in largeconsumption products. This recognition was an idea of a few influential individuals (the architect Gio Ponti, the deputy of 'La Rinascente' Cesare Brustio, and the critic Augusto Morello) following a successful exhibit in 1953. The jury included art critics, leaders in the design field, distinguished lecturers, and historians. From 1959 to 1965, the competition was co-organised by the Association for Industrial Design (Associazione per il Disegno Industriale, ADI), which took charge in 1965 (Wulfing, 2003). ADI was the third significant organisation. Founded in 1956 with the goal of supporting manufacturers and practitioners in the field through forums, exhibitions and other events, this competition includes a preselection by design experts (critics, historians, journalists, designers, architects, and professors). The jury is international with more than five members selected randomly from a pool of qualified researchers and experts from several industries (Dell'Era and Verganti, 2010). To date, 1,080 practitioners and 238 design-dominated firms are members of the Association. ${ }^{11}$ The fourth was the organisation of the Salone Internazionale del Mobile (International Furniture Exhibition), which first took place in Milan in September 1961 and included 328 exhibitors and attracted more than 10,000 visitors (Sparke, 1986). Since then, the yearly Salone has become central to the advancement of design knowledge, and Milan a

\footnotetext{
${ }^{10}$ Source: www.triennale.org (access date: 10/09/2011).

${ }^{11}$ Source: www.adi-design.org//elenco-soci.html (access date: 10/09/2011).
} 
key hub for the diffusion and promotion of Italian design where exhibitors and visitors discuss potential collaborations.

The establishment of organisations and exhibitions combined with the diffusion of new materials and production processes in firms opened up unprecedented access to knowledge and new practices for exploring innovative opportunities. At the same time, the education system offered training for practitioners both at professional and graduate level - "the various schools play an important role in providing us with expertise and specialised competencies" ([f] in Table 2). Initially, firms used to rely on graduates from architecture faculties or postgraduates from design schools, prominently the Domus Academy. By mid-1990s the Polytechnic of Milan had founded the first university-based School of Industrial Design, which engaged with themes as diverse as aesthetics, ergonomics, properties of materials, sociology of space, design methods and tools, history of design, space representation, and communications. These dynamics draw attention to the articulation of design knowledge spurring from a highly diversified set of knowledge bases, including experiential know-how.

\subsection{Examples of development of new practices in design}

The technological, organisational, and institutional changes described above were accompanied by the development of new routines which were turning points in the evolution of the home furnishing sectors. Initiatives among both the educational system and firms became important for the development of new skills. Moreover, there was growing awareness that conceptual tools and the study of quantitative data had to be complemented by practical experience. As a result, collaborations between designers and craftsmen grew significantly. In the remainder of the section, we will illustrate four instances of the interplay between the process of abstraction of rules from general practice and the changing organisation of firms and industry.

\subsubsection{Technology developments and changing role of craftsmanship}

Interview data indicate that both designers and manufacturers agree that collaboration with craftsmen had important consequences for the development of design knowledge ( $[\mathrm{g}]$ in Table 2). Clearly, Italian craftsmanship underwent changes due to discoveries of new materials or technologies that, in turn, paved the way for further developments in the production processes. In the 1950s and 1960s, craftsmanship was the alternative to large-scale production and the latter was only accessible to large manufacturing firms. However, once post-war reconstruction was over, the role of craftsmen changed and small workshops were no longer 
an alternative option, but rather the loci where engineers or designers could carry out their experiments, "because the suppliers with their team of craftsmen or prototypers are the ones to spot problems, and solve them, by being able to master this problem-solving". ${ }^{12}$

Through this interaction with craftsmen, the perception of product design changed too: furniture firms began to use design expertise to combine the benefits of technologies and new materials with product ergonomics, functionality, aesthetics, and image. Returning to the case of chairs, research and experimentation began to focus on the production of plastic chairs with no particular search for a 'new' shape but mainly to produce shapes that could best exploit the properties of plastics. Another example is the use of paper in lamps, which had not been part of the Western tradition until the discovery that the passage of light through the discontinuous filters of paper generates warmth. As Branzi Andrea stated, "this is one of the elements that I have seen become widespread in contemporary industrial production”.

\subsubsection{Prototyping and training of professionals}

Technological development and regular collaboration between designers and craftsmen favoured the emergence and establishment of prototyping as a crucial step for efficient production processes. In fact, prototyping constituted the stage during which trial-and-error activities would support the blending of traditional production techniques with new design knowledge, before moving to high-volume production in manufacturing plants. This is how the chairman of Olivetti describes the importance of prototyping for Italian firms: "perhaps it is just because of our craft background and know-how that we are able to make prototypes. And the advantage comes from building more than one prototype, and choosing the best one" ([h] in Table 2).

Universities and postgraduate schools offered more structured training courses centred on the concept and techniques of prototyping in design. An examination of the curricula of two major schools of industrial design, the Polytechnic of Milan and the European Institute of Design, shows that central modules include both preliminary sketching skills required to create computer-generated 3D models and rapid prototypes, alongside principles of ergonomics, design for manufacturing production, and design for sustainability (environmental practices). As the architect Luca Scacchetti pointed out, schools were committed "towards building a more practice-oriented design professional". These aspects

\footnotetext{
${ }^{12}$ Interview with Presotto Industrie.
} 
shed light on the formalisation of knowledge rooted both in practice (e.g., sketching skills) and theory-driven domains (e.g., principles of ergonomics).

\subsubsection{New technologies and change in the skills required}

The adoption of new materials and technologies in the 1950s led by architects contributed to manufacturers becoming more specialised. For instance, Carlo Mollino launched the first tests on the use of wood in furniture manufacturing with the support of the flourishing industry in the nearby Brianza region. ${ }^{13}$ After prototyping became established as a conventional phase of product development, the breadth of testing that could be carried out was widened. Also, the very meaning of 'testing' changed: trial-and-error activities were undertaken with software, hence impacting positively on the efficient use of resources. For what concerns the educational sphere, graduate qualifications now included 'Rapid prototyping' and 'Use of Computer-Aided Design (CAD) software' as mandatory modules.

Nevertheless, interview data also indicate the perils of the growing role of software in the product development processes, as designers fall out of practice with the treatment of specific materials or the use of technology. Boffi's Marketing Director stated: "now students finish their professional high-schools, first, they only know how to work [design] with the computer, big mistake, and second, they have never tried to realise a physical prototype, thus they don't know how to bend a steel sheet, or what is feasible and what is not" ([i] in Table 2). Thus, we can see how these dynamics (e.g., prototyping being split into digital and physical processes) have shaped the design process and, in turn, the specialisation of professionals (e.g., designers involved both in the definition of the brief and the realisation of the physical prototype).

\subsubsection{Properties of materials and the 'factory of design'}

The specific properties (and requirements) of materials had an influence also on decisions concerning the organisation of manufacturing processes, the adoption of new technologies, and the development of new collaborations. Bruno Munari, a pioneer of these practices, suggested that engaging with different materials pulls research and innovation from different sources along with the acquisition of a diversified set of resources; "it is this heterogeneity that energises design". ${ }^{14}$ In fact, change in materials has effects not only on firms' knowledge bases but also on the general design patterns that emerge within the industry. Continuing with

\footnotetext{
${ }^{13}$ Interview with Colombari Rossella.

${ }^{14}$ Interview with Danese Bruno and Vodoz Jaqueline.
} 
the case of chairs, as pointed out by Andrea Baroni, a critical juncture in the modern chair story is the change from the earlier 'rationalist' conception to the modern design. In the nineteenth century, chairs had to be manufactured from wood, resulting in a rigid seat that did not flex. After the adoption of plastics and other materials, it became possible to produce a more comfortable chair owing to the wider range of shapes from which the new material could be modelled. Thus, "the firm becomes the factory of design capable of gathering resources and transforming them into opportunities for both the (external) designers and the (internal) product developers and production experts". 15

\subsection{Design knowledge and changes in firm and industry organisation}

These developments shifted the perception of design from being a one-off activity to being a process that impinges on functionality, ergonomics, and aesthetics. Accordingly, firms put in place steady collaborations with designers to develop and embrace technological innovations and meet a growing and increasingly sophisticated market demand. This approach to new product developments led to scaling up of design and production activities. Firms exploited design not only for product innovation, but also to implement production methods that would support the adoption of new materials or technologies and reproduction of the subsequent benefits through the routinisation of relevant activities. ${ }^{16}$ Firms started to 'consult' external professionals with a view to innovating processes, machinery or to developing profitable collaborations with suppliers of specific materials or technologies. These professionals came from backgrounds as diverse as architecture, engineering, and the recently-established industrial design activity. Stable relationships with client firms were motivated by a drive to learn about their production strategy and innovation capabilities, and partly influence their decision-making.

Designers began to interact with members of the in-house product development or R\&D unit of the firm (the so-called 'ufficio tecnico', i.e., the office of technicians) for a twofold reason: first, designers had to be familiar with the resources, including skills, technologies, and production capabilities of the firm; second, the role of designers was key to reconcile the purely engineering-oriented approach of engineers or technicians with the aesthetic properties of the new product. Thus the formalisation of design knowledge necessitates, and is nurtured by, a highly diversified set of skills and competencies (Yoshikawa, 1993).

\footnotetext{
${ }^{15}$ Interview with Alessi Alberto.

${ }^{16}$ Interview with Baleri Enrico.
} 
Alberto Alessi provides an insightful example of how firms adjusted to new technologies and materials. His firm was using the cold presswork technology for steel treatment while innovative and more efficient ways to develop new products were being discovered (e.g., traditional technology required nearly 100 operations to produce a stainless steel coffee maker, whereas the immersion technology was quicker and more suitable for more complex shapes). Traditional specialisations were locking the firm into existing technologies, but the surrounding dynamics "spontaneously forced" Alessi's opening up to new materials, machinery, and technologies. Adjustments took place even in the adoption of other new materials too, such as porcelain, crystal glass, and plastics. ${ }^{17}$

As design knowledge was being formalised, changes occurred also at the organisational level. According to an interviewee, designers entered organisations "through the back door", meaning that, although design was not occupying a clear-cut space within organisations, the role of designers became crucial for innovation. As a result, while collaborations with external professionals were still ongoing, firms also started to develop design expertise inhouse, most often within the domain of the R\&D department, and it could comprise a wide range of skills and competencies, "from the painter to the varnisher, from the expert of polyurethane to that of plastics", as stated by the founder and chairman of B\&B Piero Busnelli. Indeed, interviews highlight that over the last decade firms have started to recruit design graduates whose role is key to connect the external designer with the product development department, and in particular, the team of engineers ([j] in Table 2). This has seen changes in internal firm organisation (for example, enlarging R\&D department to encompass design skills) and also institutional changes (availability of new education programmes, for instance).

\section{Discussion}

Building on the empirical evidence discussed above, it is now time to reflect back on the conceptual framework laid out in Section 2. The developments of aircraft engineering (Vincenti, 1990), chemical engineering (Rosenberg, 1998a), or the machine tool industry (Rosenberg, 1976b) recounted above are exemplary of emergent processes based mainly on the recombination of well-defined knowledge domains. In the language of Herbert Simon, these areas of expertise deal with closed problems, that is, problems whose solutions can be drawn from an identifiable set (Simon, 1969). Instead, design is akin to activities like

\footnotetext{
${ }^{17}$ Interview with Alessi Alberto.
} 
computer system design and consultancy, in that it deals with open (or "wicked" - see Rittel and Webber, 1973) problems that require a mix of social perceptiveness and creativity to be solved, and for which learned solutions can rarely be replicated. This peculiarity carries important organisational consequences for the nature and the implementation of feedback mechanisms. While feedback systems in the domain of engineering are designed to respond to the physical failure of a structure, design solutions emerge in response to cumulative understanding and redefinition of problems. Accordingly, the feedback mechanisms are not only oriented to fixing numerical parameters but, also, to interpret and, to some extent, shape social perception of artefacts (Verganti, 2008). This lack of linear relationship between failure and problem entails that the know-how needed to counter design problems draws on a diverse mix of professional skills (Consoli and Elche, 2013). In the remainder of the section we reflect on the lessons that our findings provide on (i) the systematisation and reconfiguration of new know-how and (ii) the effects of knowledge systematisation and reconfiguration on firm and industry organisation.

\subsection{Why do knowledge systematisation and reconfiguration matter?}

The case study material presented above illustrates how design has become, in this as much as in many other industrial contexts, a staple of innovation strategy. Firms integrate design activities and develop the associated skills to promote the emotional and symbolic aspects of products. Put otherwise, design is not just involved in lending the product a nicer form, but also in anticipating needs or proposing a new 'vision' to users. Much of the work in design is about synthesis and integration as much as it is about understanding values and meanings in society, and their impact on product language (Utterback et al., 2006). It is however difficult to track the process through which designers develop knowledge about future socio-cultural models because this is tacit, distributed, and dependent on interactions between users, firms, artists, and the education system. Indeed, designers' knowledge resides in the capability to access this network of interactions and act as an intermediary or 'broker' of these signs across a range of industries (Utterback et al., 2006). As the interaction between formerly unrelated professionals (such as prototypers, designers, art directors, and materials experts) grows, new inter-organisational connections flourish at meso level. This does not happen in a single iteration but, rather, in a cumulative sequence across industry ecology, knowledge emergence and diffusion, and progressive division of labour (e.g., new organisations or exhibitions, new functions or organisational roles). 
In this context knowledge systematisation embraces the abstraction of parametric and symbolic meanings while reconfiguration concerns the progressive conversion and formalisation of these novel practices within existing firm and industry organisation. The interdependent transformations underpinning the interplay between the two processes are illustrated with the aid of Figure 1: change of technologies (T); of materials (M); of the activities carried out by furniture manufacturers (FM) or other sectors (OS) (such as lighting or white appliances, for example); changes in the qualifications provided by the education system (E); emergence of new types of organisations (NO); and finally, emergence of new professional roles $(\mathrm{P})$. This shows how the expertise of craftsmen gained importance and evolved from being a mere alternative to high-volume production to being a crucial complement for experiments on prototypes and for the completion of projects in which design knowledge could not easily be routinised. The expansion of small workshops is illustrative of the transformations that took place both in the knowledge base of the firm and in firm and industry organisation, whereby the necessity to embed experimental knowledge into NPD processes (Rosenberg, 1998a) fostered interaction between manufacturing firms, production experts, and designers. The education system saw adaptation and change as both professional and graduate schools expanded the training (and adapted the content of such training) for design professionals (e.g., undergraduate degrees in industrial design, training courses on rapid prototyping and ergonomics).

Figure 1 about here

Figure 1 illustrates the co-evolution of different knowledge bases, different technologies, and different specialisations: for each event or sequence of events there follows a specification of the nature of the actual change in knowledge systematisation (KS) or reconfiguration (KR) brought by a specific event, and the influence on the organisation of firm (Firm) or industry (Industry). But our analysis also highlights the mutual influence between socio-cultural context and industry setting. Design evolved from being perceived as a marginal concern (e.g., during wartime, design was mainly about functionality and cost-effectiveness) to becoming an essential component of products also owing to the regular organisation of events (such as exhibitions and prizes) that created engagement with a growing audience and at the same time guided their taste towards appreciating the meaning of design. While scholars have previously emphasised the importance of these events for the identification of technological 
and market opportunities (Maskell et al., 2007), this research uncovers the extent to which the environment within which firms operate provides feedback and supports the diffusion of novel practices.

Our initial statement was that systematisation and reconfiguration are pathways to make useful new knowledge relevant for the wider remit of firms and industries. The extent to which this is true, however, depends on how specialised firms (re)organise all or part of the business activity and bring transformations in firm and industry organisation (Rosenberg, 1963; Sturgeon, 2002). The next section will elaborate these points further.

\subsection{What consequences for the organisation of firms and industry?}

The progressive integration of designers within manufacturing processes is a clear example of how knowledge systematisation and reconfiguration mechanisms influence firm and industry organisation. This process can be ascribed to a generalised increase in capital intensity (Katz and Margo, 2013) as well as widespread transformation of practice, whereby a 'hands-on' approach had shown to be most effective for designers in understanding the language of other professionals, translating it into product characteristics and functionality, and to interfacing with managers for strategic purposes. Broadly speaking, firms' engagement with experts led to increased professionalisation, and to the establishment of new professional roles. Parallel to this, prototyping developed with different characteristics compared to other fields: while, for example, in aeronautics it was conceived as a methodology (Wilson and Wilson, 1965; Dreyfuss, 1974), in furniture it developed as a stage of the production process essential to assess the feasibility and reaction of a material to certain conditions. Our analysis depicts the micro-level mechanisms through which new firm roles emerge (such as the art director or materials expert) and new organisations and institutions at the industry level develop (e.g., establishment of design exhibitions and industry associations). These reflected back on the inter-organisational dynamics as firms' behaviour was influencing the activities undertaken by other organisations (development of qualifications both at professional and graduate levels). For instance the subject 'Innovation through materials and technologies' was increasingly common within the design, architecture and engineering degrees. In the context of professional domains such as medicine and law, formal recognition is gained by the establishment of a professional body whose main task is the mitigation of conflicts and power struggles (Barber, 1963; Parsons, 1968; Etzioni, 1969). In the case of design, however, the process unfolded differently as the various activities were being recognised and implemented 
within firms and the industry. This generated new ways of organising knowledge in labour and in production, which contributed to and reinforced the foundations of the emerging business activity or function.

Furthermore, Rosenberg and Vincenti (1978:2) maintain that learning from failure is fundamental for advancing knowledge and that "technological change can most fruitfully be examined as a problem-solving activity". Their underlying assumption is that the satisfaction of needs of multiple actors (i.e., firms, industries, and experts) is achieved in scientific laboratories purposefully set up for trial and error. The case of design goes beyond, and illustrates that potentially valuable experimental activities are strictly interwoven with intangible aspects such as tastes and dominant culture. Thereby the key actors therein need not only be able to learn and apply pre-specified analytical criteria but also to influence the setting, for instance by testing and generating new meanings in the 'living lab' of society. The case study presented above calls attention also to the role that masters (aka experts in undertaking a given set of practices) play in innovation (Jones and Bouamane, 2011). The professionalisation of design unfolds via informal routines or practices (i.e., demand for newly combined skills and subsequent emergence of a specialised knowledge base) as well as industry-wide routines or practices (i.e., credentialism in the job market and accreditation via curricula development). Whilst new machinery is developed to replace human skills (e.g., introduction of CAD software), the activities enabled by the adoption of these new technologies also broaden the problem space and, hence, the solutions required. This, in turn, opens room for further developments such as the establishment of a new industry or a new discipline. This latter aspect is coherent with the experiences recounted by Rosenberg (1963) and Vincenti (1990). The pathways through which these trajectories emerge, however, are different for design, which offers an opportunity to bridge the practices tradition and the (neo)institutionalist debate mentioned above. ${ }^{18}$

Last but not least, the focus on knowledge systematisation and reconfiguration elucidate the importance of education and training systems. The evolution of undergraduate and postgraduate design programmes points towards the establishment of an autonomous body of knowledge (Vincenti, 1990). However, it is important to appreciate the extent to which this may hinder originality and heterodox thinking among design professionals. As Baumol (2005) suggests, there is a trade-off between education focused on technical competence and mastery

\footnotetext{
${ }^{18}$ We thank an anonymous referees for bringing this issue to our attention.
} 
of currently available analytical tools and education that aims at fostering creativity and imagination. Greater emphasis on either may hamper rather than facilitate innovation. The empirical evidence illustrated earlier shows that practical knowledge is essential for designers to encourage innovation within firm product development processes and support changes in knowledge bases. But the role of professional education should not be downplayed. Extending Jones and Bouamane's (2011) argument, we argue that the establishment of a new knowledge domain requires that the education system play a catalysing role in formalising the emerging practices in parallel to a collective understanding of routines grounded in practice, especially when knowledge does not lend itself to easy formalisation, creativity is imperative, and obstacles to diffusion are more likely to arise.

\section{Concluding remarks}

The paper has analysed two pathways through which design knowledge becomes economically relevant, namely: systematisation, that is, the abstraction of operative principles for facilitating the diffusion of new practices; and reconfiguration, that is, the development of new routines and the reorganisation of existing ones. The interplay between the two processes embraces different levels of organisation, namely: the contribution of practical knowledge to capability development within firms; the trial-and-error adoption of novel production criteria; the impact of new technologies on the development of new skills and emergence of new organisational roles. The analysis illustrates the cyclical process by which certain practices shape organisational choices and how these encourage broader adjustments at industry level, such as response in training and professional education system.

The focus on the design activity has afforded a closer look into a context in which analytical, synthetic and symbolic knowledge are jointly articulated. The goal of professional designers is to strike a compromise between physical properties of materials and aesthetics judgment. They are concerned with objective characteristics of the technology involved (as is engineering) as well as the formal qualities of products, the emotional and symbolic sides, and how functionality is delivered to users. The test of the final product entails not only a technical assessment in a lab but also an evaluation of how the symbolic meaning embedded in the artefact is perceived. Design professionals master craftsmanship, knowledge of materials, and awareness of lifestyles, product cultural dimensions, or tastes. These parameters, based on knowledge that is partly tacit, provide a common ground and language 
that can be used across a range of industries. The instituted processes that have been discussed in this paper ensure the survival and growth of this particular knowledge base.

At a conceptual level, these findings offer a nuanced view of the interplay across individual skills, routines, and changing organisation of firm and industry. On the one hand, we recount the process that facilitates the diffusion of operative principles. On the other hand, we analyse the array of transformations that are necessary in firm and industry organisation to accommodate said novel know-how. Design activities, it has been argued, are an interesting case in point given the breadth of organisations involved, the range of sub-sectors they contribute to, and the different sets of expertise, skills, and techniques that their implementation entails. The paper emphasises how the evolution of skills and routines and the role of institutions both at micro and meso level are central to these transformations. Finally the present study moves further the research agenda laid out by Ravasi and Stigliani (2012) towards better understanding of the pathways through which design shapes innovation. Whilst this research elucidates the effects of the development of a business activity or function based on creativity (as well as technological and professional knowledge), and focuses on the intricate nexus of knowledge dynamics at firm and industry level, the idiosyncratic nature of design can be a limitation of this study. However we believe that further effort should be addressed towards understanding how the changing know-how in terms of new practices influences firm and industry organisation. That will continue to be our next project.

Acknowledgements. We are indebted to Stan Metcalfe and Richard Nelson for insightful comments on previous versions of the manuscript. The thought-provoking comments of three referees and of the editor allowed us to improve the manuscript substantially. Preliminary drafts were presented at the 2011 EAEPE Annual Conference, 2012 DRUID Summer Conference and 2013 MOTI Seminar Series at Grenoble Ecole de Management. On those occasions we benefited from comments by Lori Rosenkopf, Sarah Kaplan and Jonatan Pinkse. BD acknowledges financial support from the Economic and Social Research Council (ES/F022735/1). MM acknowledges financial support from the Economic and Social Research Council (RES-189-25-0227). DC acknowledges financial support from the European Community (FP7-PEOPLE-IEF-2008-235278). The opinions expressed in this paper are those of the authors. The usual caveats apply. 


\section{References}

Balconi, M., 2002. Tacitness, codification of technological knowledge and the organisation of industry. Research Policy 31, 357-379.

Baldwin, C.Y., Clark, K.B., 2000. Design rules: The power of modularity. MIT Press, Cambridge, MA.

Barber, B., 1963. Some problems in the sociology of the professions. Daedalus 92, 669-688.

Basalla, G., 1988. The Evolution of Technology. Cambridge University Press, Cambridge.

Baumol, W.J., 2005. Education for innovation: entrepreneurial breakthroughs versus corporate incremental improvements. Innovation Policy and the Economy 5, 33-56.

Best, M., 2001. The New Competitive Advantage: The Renewal of American Industry. Oxford University Press, Oxford.

Candi, M., 2010. Benefits of aesthetic design as an element of new service development. Journal of Product Innovation Management 27, 1047-1064.

Chandler, A.D., 1977. The Visible Hand: The Managerial Revolution in American Business. Harvard University Press, Cambridge, MA.

Chiva, R., Alegre, J., 2007. Linking design management skills and design function organization: an empirical study of Spanish and Italian ceramic tile producers. Technovation 27, 616-627.

Chiva, R., Alegre, J., 2009. Investment in design and firm performance: the mediating role of design management. Journal of Product Innovation Management 26, 424-440.

Cohen, M.D., 2007. Reading Dewey: reflections on the study of routine. Organization Studies 28, 773-786.

Cohen, M.D., Bacdayan, P., 1994. Organizational routines are stored as procedural memory: evidence from a laboratory study. Organization Science 5, 554-568.

Consoli, D., Elche, D., 2013. The evolving knowledge base of professional service sectors. Journal of Evolutionary Economics 23, 477-501.

Constant II, E.W., 1980. The origins of the turbojet revolution. Johns Hopkins University Press, Baltimore.

Cragg, C.B., 1989. Evolution of the steam engine, in: Hahlweg, K., Hooker, C.A. (Eds.), Issues in Evolutionary Epistemology. SUNY Press, Albany, pp. 313-356.

D'Adderio, L., 2008. The performativity of routines: theorising the influence of artefacts and distributed agencies on routines dynamics. Research Policy 37, 769-789.

David, P.A., 1975. Technical choice innovation and economic growth. Essays on American and British experience in the nineteenth century. Cambridge University Press, Cambridge, UK.

Dell'Era, C., Verganti, R., 2010. Collaborative strategies in design-intensive industries: knowledge diversity and innovation. Long Range Planning 43, 123-141.

D'Ippolito, B., 2014. The importance of design for firms' competitiveness: a review of the literature. Technovation.

Dreyfuss, H., 1974. Designing for people. Paragraphic, New York.

Dumas, A., Whitfield, A., 1989. Why design is difficult to manage: a survey of attitudes and practices in British industry. European Management Journal 7, 50-56.

Dyer, W.G., Wilkins, A.L., 1991. Better stories, not better constructs, to generate better theory: a rejoinder to Eisenhardt. Academy of Management Review 16, 613-619. 
Eisenhardt, K.M., 1989. Building theories from case study research. Academy of Management Review 14, 532-550.

Eisenhardt, K.M., Graebner, M.E., 2007. Theory building from cases: opportunities and challenges. Academy of Management Journal 50, 25-32.

Etzioni, A., 1969. The semi-professions and their organization: teachers, nurses, social workers. The Free Press, New York.

Falabrino, G.L., 2004. Design speaks Italian. Domus Academy story. Libri Scheiwiller, Milan.

Filippetti, A., 2010. Harnessing the 'essential tension' of design: the complex relationship between the firm and designer consultant, in: Series, W.P. (Ed.). MPRA Munich Personal RePEc Archive, Munich, pp. 1-22.

Findeli, A., 1991. Design education and industry: the laborious beginnings of the Institute of Design in Chicago in 1944. Journal of Design History 4, 97-113.

Gemser, G., Leenders, M.A., 2001. How integrating industrial design in the product development process impacts on company performance. Journal of Product Innovation Management 18, 28-38.

Gray, D.E., 2004. Doing research in the real world. SAGE, London.

Greenwood, R., Suddaby, R., Hinings, C.R., 2002. Theorizing change: the role of professional associations in the transformation of institutionalized fields. Academy of Management Journal 45, 58-80.

Hau, E., 2000. Wind turbines: fundamentals, technologies, application, economics. Springer, Berlin.

Hertenstein, J.H., Platt, M.B., Veryzer, R.W., 2005. The impact of industrial design effectiveness on corporate financial performance. Journal of Product Innovation Management 22, 3-21.

Hevner, A.R., March, S.T., Park, J., 2004. Design science in Information Systems research. MIS Quarterly 28, 75-105.

Heymann, M., 1998. Signs of hubris: the shaping of wind technology styles in Germany, Denmark, and the United States, 1940-1990. Technology and Culture 39, 641-670.

Hounshell, D.A., 1984. From the American System to Mass Production 1800-1932: The Development of Manufacturing Technology in the United States. The John Hopkins University Press, Baltimore.

Jones, G., Bouamane, L., 2011. Historical trajectories and corporate competences in wind energy, Harvard Business School Working Paper no. 11-112, pp. 1-82.

Katz, L.F., Margo, R.A., 2013. Technical change and the relative demand for skilled labor: the United States in historical perspective. Revision of a paper presented at the "Human Capital and History: The American Record" Conference, Cambridge MA, December.

King, N., 2004. Using template analysis in the thematic analysis of text, in: Symon, G., Cassell, C. (Eds.), Qualitative methods and analysis in organizational research: a practical guide. Sage Publications, Thousand Oaks, CA, pp. 256-270.

Kotler, P., Rath, G.A., 1984. Design: a powerful but neglected strategic tool. Journal of Business Strategy 5, 16-21.

Langley, A., 1999. Strategies for theorizing from process data. The Academy of Management Review 24, 691-710.

Lees-Maffei, G., 2008. Introduction: professionalization as a focus in interior design history. Journal of Design History 21, 1-18. 
Lesko, J., 1996. Industrial design at Carnegie Institute of Technology, 1934-1967. Journal of Design History 10, 269-292.

Lojacono, G., Zaccai, G., 2004. The evolution of design-inspired enterprises. MIT Sloan Management Review 45, 75-79.

Love, T., 2002. Constructing a coherent cross-disciplinary body of theory about designing and designs: some philosophical issues. Design Studies 23, 345-361.

Luchs, M., Swan, S., 2011. Perspective: the emergence of product design as a field of marketing inquiry. Journal of Product Innovation Management 28, 327-345.

March, S.T., Smith, G.F., 1995. Design and natural science research on information technology. Decision Support Systems 15, 251-266.

Maskell, P., Pedersen, T., Petersen, B., Dick-Nielsen, J., 2007. Learning paths to offshore outsourcing: from cost reduction to knowledge seeking. Industry and Innovation 14, 239 257.

Miles, M.B., Huberman, A.M., 1994. Qualitative data analysis. Sage, Thousand Oaks, CA.

Miozzo, M., Grimshaw, D., 2011. Capabilities of large services outsourcing firms: the 'outsourcing plus staff transfer model' in EDS and IBM. Industrial and Corporate Change 20, 909-940.

Miozzo, M., Walsh, V., 2006. International competitiveness and technological change. Oxford University Press, Oxford.

Mokyr, J., 2002. The gifts of Athena: historical origins of the knowledge economy. Princeton University Press, Oxford.

NACE, 2008. Correspondence Table NACE Rev. 2 - NACE Rev. 1.1, pp. 1-56.

Nelson, R.R., 2003. On the uneven evolution of human know-how. Research Policy 32, 909922.

Nelson, R.R., Winter, S.G., 1982. An evolutionary theory of economic change. Belknap Press, London.

Nielsen, K.H., 2010. Technological trajectories in the making: two case studies from the contemporary history of wind power. Centaurus 52, 175-205.

Nightingale, P., 2000. The product - process - organisation relationship in complex development projects. Research Policy 29, 913-930.

Noble, D.F., 1977. America by Design. Science, Technology, and the Rise of Corporate Capitalism. Alfred A. Knopf, Inc., New York.

Parsons, T., 1968. The professions. International Encyclopedia of the Social Sciences 12, 536547.

Perks, H., Cooper, R., Jones, C., 2005. Characterizing the role of design in new product development: an empirically derived taxonomy. Journal of Product Innovation Management 22, 111-127.

Potter, S., Roy, R., Capon, C.H., Bruce, M., Walsh, V., Lewis, J., 1991. The benefits and costs of investment in design: using professional design expertise in product engineering and graphics projects. The Open University and UMIST, Milton Keynes.

Raimondi, G., 1990. Italian living design: Three decades of interior decoration 1960-1990 (C.L. Rathman, Trans.). Rizzoli, New York.

Ravasi, D., Lojacono, G., 2005. Managing design and designers for strategic renewal. Long Range Planning 38, 51-77.

Ravasi, D., Stigliani, I., 2012. Product design: a review and research agenda for management studies. International Journal of Management Reviews 14, 464-488. 
Rittel, H.W.J., Webber, M.M., 1973. Dilemmas in a general theory of planning. Policy Sciences 4, 155-169.

Rosenberg, N., 1963. Technological change in the machine tool industry. The Journal of Economic History 23, 414-443.

Rosenberg, N., 1976a. Perspectives on Technology. M. E. Sharpe, New York.

Rosenberg, N., 1976b. Technological change in the machine tool industry, 1840-1910, in: Rosenberg, N. (Ed.), Perspectives on Technology. M. E. Sharpe, New York, pp. 9-31.

Rosenberg, N., 1998a. Chemical engineering as a general purpose technology, in: Helpman, E. (Ed.), General purpose technologies and economic growth. MIT Press, London.

Rosenberg, N., 1998b. Technological change in chemicals: the role of university-industry relations, in: Arora, A., Landau, R., Rosenberg, N. (Eds.), Chemicals and Long-Term Economic Growth. John Wiley, New York.

Rosenberg, N., Steinmueller, W.E., 2013. Engineering knowledge. Industrial and Corporate Change 22, 1129-1158.

Rosenberg, N., Vincenti, W.G., 1978. The Britannia Bridge: the generation and diffusion of technological knowledge. MIT Press, London.

Rothwell, R., Gardiner, P., 1983. The role of design in product and process change. Design Studies 4, 161-169.

Roy, R., Wield, D., 1986. Product design and technological innovation: a reader. Open University Press, Milton Keynes.

Salvato, C., 2009. Capabilities unveiled: the role of ordinary activities in the evolution of product development processes. Organization Science 20, 384-409.

Simon, H.A., 1969. The Sciences of the Artificial. MIT Press, London.

Smets, M., Morris, T.I.M., Greenwood, R., 2012. From practice to field: a multilevel model of practice-driven institutional change. Academy of Management Journal 55, 877-904.

Sparke, P., 1986. Did Britain make it? British design in context 1946-86. Design Council, London.

Sturgeon, T.J., 2002. Modular production networks: a new American model of industrial organization. Industrial and Corporate Change 11, 451-496.

Suddaby, R., 2006. From the editors: what grounded theory is not. Academy of Management Journal 49, 633-642.

Swink, M., 2000. Technological innovativeness as a moderator of new product design integration and top management support. Journal of Product Innovation Management 17, 208-220.

Tolbert, P.S., Zucker, L.G., 1996. The institutionalization of institutional theory, in: Clegg, S., Hardy, C., Nord, W. (Eds.), Handbook of Organization Studies. SAGE, London, pp. 175190.

Utterback, U., Vedin, B.A., Alvarez, E., Ekman, S., Sanderson, S.W., Tether, B.S., Verganti, R., 2006. Design-inspired innovation. World Scientific Publishing, Singapore.

van der Aa, W., Elfring, T., 2002. Realizing innovation in services. Scandinavian Journal of Management 18, 155-171.

Verganti, R., 2003. Design as brokering of languages: innovation strategies in Italian firms. Design Management Journal 14, 34-42.

Verganti, R., 2008. Design, meanings, and radical innovation: a metamodel and a research agenda. Journal of Product Innovation Management 25, 436-456. 
Veryzer, R.W., 2005. The roles of marketing and industrial design in discontinuous new product development. Journal of Product Innovation Management 22, 22-41.

Vincenti, W.G., 1990. What engineers know and how they know it. Analytical studies from aeronautical history. The John Hopkins University Press, London.

von Stamm, B., 2008. Managing innovation, design and creativity. John Wiley \& Sons, Chichester.

Vona, F., Consoli, D., 2011. Innovation and skill dynamics: a life-cycle approach, Documents de Travail 2011-26, Observatoire Français des Conjonctures Economiques (OFCE).

Walsh, V., 1996. Design, innovation and the boundaries of the firm. Research Policy 25, 509529.

Walsh, V., Roy, R., 1983. Plastic products: good design, innovation and business success, in: DIG-01, R. (Ed.), DIG no 1. The Open University and UMIST, Milton Keynes.

Walsh, V., Roy, R., Bruce, M., 1988. Competitive by design. Journal of Marketing Management 4, 201-216.

Walsh, V., Roy, R., Bruce, M., Potter, S., 1992. Winning by design: technology, product design and international competitiveness. Blackwell Publishers, Oxford.

Wilson, I.G., Wilson, M.E., 1965. Information, computers, and system design. Wiley, London.

Wulfing, K.W., 2003. Compasso d'Oro and changes in the Italian domestic landscape, College of Architecture and Urban Studies. Virginia Polytechnic Institute and State University, Virginia, pp. 1-89.

Yin, R., 2009. Case study research: design and methods, 4th ed. Thousand Oaks - 4th Edition, California.

Yoshikawa, H., 1993. Systematization of design knowledge. Annals of the CIRP 42, 131-134.

Ziman, J., 2000. Technological innovation as an evolutionary process. Cambridge University Press, Cambridge. 
Table 1: Sampled firms (data as of June 2011)

\begin{tabular}{|c|c|c|c|c|c|c|c|c|}
\hline Firm & Location & Size $^{(1)}$ & $\begin{array}{l}\text { Location of } \\
\text { design }^{(2)}\end{array}$ & $\begin{array}{c}\text { Ma } \\
\text { home }\end{array}$ & $\begin{array}{l}\text { ket } \\
\text { foreign }\end{array}$ & $\begin{array}{l}\operatorname{Area}(\mathbf{s}) \text { of } \\
\text { expertise }\end{array}$ & Design expertise & Highlights \\
\hline Aran World & Pesaro & Large & I\&ED & $30 \%$ & $70 \%$ & Kitchen, office & $\begin{array}{l}\text { Design department ( } 10 \text { designers); } \\
\text { product development department } \\
\text { well established; collaborations with } \\
3-5 \text { external designers }\end{array}$ & $\begin{array}{l}\text { Among the pioneers in producing furniture } \\
\text { modular systems; among top exporters of } \\
\text { kitchen and office furniture; on the cutting } \\
\text { edge for environment-friendly initiatives }\end{array}$ \\
\hline Boffi & Milan & Large & ED & $35 \%$ & $65 \%$ & $\begin{array}{l}\text { Living rooms, } \\
\text { bathrooms }\end{array}$ & $\begin{array}{l}\text { R\&D department ( } 3 \text { members of staff); } \\
\text { product development department } \\
\text { ( } 4 \text { engineers); collaborations with } \\
\text { renowned external designers }\end{array}$ & $\begin{array}{l}\text { Developing internal expertise in lighting; } \\
\text { member of the Fondazione Altagamma, a } \\
\text { foundation that gathers all Italian luxury } \\
\text { companies known for their design }\end{array}$ \\
\hline Citterio & Milan & medium & $\mathrm{ED}$ & $\mathrm{n} / \mathrm{a}$ & $\mathrm{n} / \mathrm{a}$ & $\begin{array}{l}\text { Office, living } \\
\text { rooms, contract }\end{array}$ & $\begin{array}{l}\text { Product development department; } \\
\text { regular collaboration with external } \\
\text { designers (emphasis on their } \\
\text { reputation) }\end{array}$ & $\begin{array}{l}\text { Market leader in the European office wall } \\
\text { sector since the 1980s; development of an } \\
\text { integrated system of design, production, } \\
\text { and service to achieve global quality }\end{array}$ \\
\hline Dieffebi & Treviso & Medium & ED & $28 \%$ & $72 \%$ & Office, contract & $\begin{array}{l}\text { Product development department } \\
\text { ( } 3 \text { engineers); collaborations with } \\
\text { external designers }\end{array}$ & $\begin{array}{l}\text { Specialised in the development and } \\
\text { manufacturing of metal-based furniture }\end{array}$ \\
\hline Edra & Pisa & Medium & I\&ED & $\mathrm{n} / \mathrm{a}$ & $\mathrm{n} / \mathrm{a}$ & Living rooms & Product development department & $\begin{array}{l}\text { Main customer target: high-end segment; key } \\
\text { role played by the art director, a designer } \\
\text { renowned within the global design scene }\end{array}$ \\
\hline Lago & Padua & Medium & ID & $\mathrm{n} / \mathrm{a}$ & $\mathrm{n} / \mathrm{a}$ & $\begin{array}{l}\text { Living rooms, } \\
\text { bathrooms }\end{array}$ & $\begin{array}{l}\text { Design department ( } 3 \text { designers, } \\
\text { including the President, the firm's } \\
\text { art director); product development } \\
\text { department ( } 5 \text { technical experts, } \\
1 \text { materials expert) }\end{array}$ & $\begin{array}{l}\text { Longstanding tradition in the manufacturing } \\
\text { of wooden furniture, then switch to plastics } \\
\text { newer materials; particularly oriented } \\
\text { towards spurring a creative-thinking } \\
\text { environment across the different departments }\end{array}$ \\
\hline Luceplan & Milan & Medium & I\&ED & $20 \%$ & $80 \%$ & Lighting systems & $\begin{array}{l}\text { Product development department } \\
\text { (industrial designers and engineering } \\
\text { designers); collaboration with few, } \\
\text { trusted external designers }\end{array}$ & $\begin{array}{l}\text { Strong specialisation in one segment } \\
\text { (lighting design); collaborations with R\&D } \\
\text { research centres of multinationals (e.g., } \\
\text { Philips) }\end{array}$ \\
\hline
\end{tabular}

(1) Micro: turnover $<€ 2 \mathrm{mln}$; Small: turnover $<€ 10 \mathrm{mln}$; Medium: turnover $<€ 50 \mathrm{mln}$ (see definition of SMEs provided in the Commission Recommendation 2003/361/EC).

(2) ID: in-house design team or department. ED: the firm collaborates with external designers. I\&ED: internal design team collaborating with external professional designers. 


\section{Table 1 (continued)}

\begin{tabular}{|c|c|c|c|c|c|c|c|c|}
\hline Firm & Location & Size $^{(1)}$ & $\begin{array}{l}\text { Location of } \\
\text { design }^{(2)}\end{array}$ & $\begin{array}{r}\mathrm{M} \\
\text { home }\end{array}$ & $\begin{array}{l}\text { rket } \\
\text { foreign }\end{array}$ & $\begin{array}{l}\text { Area(s) of } \\
\text { expertise }\end{array}$ & Design expertise & Highlights \\
\hline Magis & Treviso & Medium & ED & $15 \%$ & $85 \%$ & $\begin{array}{l}\text { Living rooms } \\
\text { contract }\end{array}$ & $\begin{array}{l}\text { Product development department; } \\
\text { regular collaboration with external } \\
\text { designers (emphasis on reputation) }\end{array}$ & $\begin{array}{l}\text { Main customer target: high-end market } \\
\text { segment; new specialisations recently } \\
\text { developed }\end{array}$ \\
\hline Molteni\&C & Milan & Large & ED & $45 \%$ & $55 \%$ & $\begin{array}{l}\text { Living rooms, } \\
\text { office, bedrooms } \\
\text { contract }\end{array}$ & $\begin{array}{l}\text { Product development department; } \\
\text { art director; preference towards } \\
\text { collaborating with an established } \\
\text { network of designers }\end{array}$ & $\begin{array}{l}\text { Major Italian group within the home } \\
\text { furnishing sector, with a worldwide } \\
\text { reputation; strong collaborations with } \\
\text { external R\&D centres; attempt to create } \\
\text { synergies between the different business } \\
\text { units (e.g., living room, office, kitchen) }\end{array}$ \\
\hline Mussi & Milan & Micro & ED & $40 \%$ & $60 \%$ & Bedrooms & $\begin{array}{l}\text { Collaboration with external designers, } \\
\text { selected by the (external) Art Director }\end{array}$ & $\begin{array}{l}\text { A 'tailor's shop' for home furnishing; despite } \\
\text { the small size, the company is trying to } \\
\text { manufacture according to international } \\
\text { design and technical standards }\end{array}$ \\
\hline Ozzio Design & Milan & Small & ED & $60 \%$ & $40 \%$ & Living rooms & $\begin{array}{l}\text { Product development department; } \\
\text { regular collaborations with external } \\
\text { designers }\end{array}$ & $\begin{array}{l}\text { Specialised in design and development of } \\
\text { tables and chairs ('Move your space' motto); } \\
\text { most of the subcomponents are manufactured } \\
\text { by an established network of suppliers }\end{array}$ \\
\hline $\begin{array}{l}\text { Presotto } \\
\text { Industrie }\end{array}$ & Pordenone & Medium & ED & $60 \%$ & $40 \%$ & $\begin{array}{l}\text { Bedrooms, living } \\
\text { rooms, contract }\end{array}$ & $\begin{array}{l}\text { Product development department; } \\
\text { regular collaboration with external } \\
\text { designers }\end{array}$ & $\begin{array}{l}\text { Strong connection between the R\&D and the } \\
\text { marketing departments; highly engaged with } \\
\text { local actors (e.g., education institutions, } \\
\text { sector-specific trade associations) }\end{array}$ \\
\hline SMA & Treviso & Medium & ED & $50 \%$ & $50 \%$ & $\begin{array}{l}\text { Bedrooms, living } \\
\text { rooms }\end{array}$ & $\begin{array}{l}\text { Product development department; } \\
\text { regular collaboration with external } \\
\text { designers, carefully selected by the } \\
\text { (internal) art director }\end{array}$ & $\begin{array}{l}\text { Engagement with Federlegno (Italian } \\
\text { association of wood manufacturers); } \\
\text { aggressive strategy in both the home and } \\
\text { foreign markets }\end{array}$ \\
\hline Valcucine & Pordenone & Medium & ID & $60 \%$ & $40 \%$ & $\begin{array}{l}\text { Kitchen, living } \\
\text { rooms }\end{array}$ & $\begin{array}{l}\text { Product development department; } \\
\text { internal art director; design } \\
\text { department }\end{array}$ & $\begin{array}{l}\text { Highly proactive in terms of environment- } \\
\text { friendly kitchen furniture; regular } \\
\text { collaborations with external R\&D centres }\end{array}$ \\
\hline
\end{tabular}

(1) Micro: turnover $<€ 2 \mathrm{mln}$; Small: turnover $<€ 10 \mathrm{mln}$; Medium: turnover $<€ 50 \mathrm{mln}$ (see definition of SMEs provided in the Commission Recommendation 2003/361/EC).

(2) ID: in-house design team or department. ED: the firm collaborates with external designers. I\&ED: internal design team collaborating with external professional designers. 


\section{Table 2: Quotes from primary and secondary interview data}

\begin{tabular}{|c|c|c|}
\hline Quote & Interviewee & Quote \\
\hline [a] & Alessi, Alberto & $\begin{array}{l}\text { "Our experimental activities with plastics allow us, for instance, to decrease substantially the average age of our consumers, and they give our designers } \\
\text { the possibility of coming up with more diversified forms compared to the cold press technique in metals." }\end{array}$ \\
\hline [b] & Boffi & $\begin{array}{l}\text { "It is important to find partners willing to collaborate. This is facilitated by our brand, it is good for the reputation of our suppliers, they will try to use our } \\
\text { materials and conduct experiments in the perspective of developing a partnership." }\end{array}$ \\
\hline [c] & Gismondi, Ernesto & $\begin{array}{l}\text { "The difficulty with manufacturing plastic furniture is twofold, of technical and economic nature. Technical because the moulds are very complex, made up } \\
\text { of alloy steel, and have to be built in order to withstand up to two thousand tons of pressure; and economic because in the late } 1960 \text { s they cost us hundreds } \\
\text { of millions lire. Given the significant amount of money involved, no mistake is tolerated." }\end{array}$ \\
\hline [d] & Valcucine & $\begin{array}{l}\text { "It is more likely that I go to the fair to learn about the treatment of magnesium, or other things that are not connected with furniture at all, in order to } \\
\text { absorb new competencies. It is owing to this approach that we have realised the thinnest cabinet door by employing technologies common in the } \\
\text { automotive sector." }\end{array}$ \\
\hline [e] & Magis & $\begin{array}{l}\text { "We rely on a solid supply chain, we collaborate with seven or eight suppliers on a regular basis, and each of them is specialised in a specific domain, } \\
\text { such as plastics treatment with standard injection, plastic treatment with gas, manufacturing of plastic tubes, die casting, etc. ... but we are a company that } \\
\text { likes to work 'on the edge', that is, we try to apply these techniques to different products, and take the risk." }\end{array}$ \\
\hline [f] & SMA & $\begin{array}{l}\text { "Here, in this area, we are surrounded (and supported) by a few education institutions. For instance, the Faculty of Arts and Architecture in Venice, the } \\
\text { University of Treviso, and along with the universities, the design history comes of help, great masters like Carlo Serafini... I mean, the various schools play } \\
\text { an important role in providing us with expertise and specialised competencies..." }\end{array}$ \\
\hline [g] & Ozzio Design & "Most of the ideas are born in-house, yet various inputs come from the designers, our suppliers, or the craftsmen we collaborate with." \\
\hline & SMA & $\begin{array}{l}\text { "We rarely need to source our suppliers, such as components or semifinished products, from far away. We can rely on the intense synergy with local } \\
\text { producers and craftsmen. Every time I have a new product idea in mind, I tend to discuss it with suppliers or craftsmen, and develop it further together." }\end{array}$ \\
\hline [h] & Castelli, Giulio & $\begin{array}{l}\text { "We [as Italians] tend to be risk-takers... someone the other evening, at the Salone, said that, 'Italians are good at making prototypes, but not } \\
\text { manufacturing them'. I would say that Italians these days are good at realising the prototypes and manufacturing the products, it is a fact that we are the } \\
\text { top exporters of furniture in the world. We are very talented, and perhaps it is just because of this craft background, this know-how that we have, that we } \\
\text { are able to make prototypes. And the advantage comes from building more than one prototype, and choosing the best one." }\end{array}$ \\
\hline [i] & Boffi & $\begin{array}{l}\text { "All the schools with a Bauhaus tradition used to focus on prototyping, and use of materials. Now students finish their professional high-schools, first, they } \\
\text { only know how to work [design] with the computer, big mistake, and second, they have never tried to realise a physical prototype, thus they don't know } \\
\text { how to bend a steel sheet, or what is feasible and what is not." }\end{array}$ \\
\hline [j] & SMA & $\begin{array}{l}\text { "Our design is a young design [...] I have always found young designers to be the most creative, they have ideas that are naturally innovative, whilst older } \\
\text { architects follow a path that has always been their own, and struggle to rebrand themselves. Young designers have this spirit, to see beyond the edge, an } \\
\text { attitude that helps to develop new products with a true potential to be successful." }\end{array}$ \\
\hline
\end{tabular}


D'Ippolito, B., Miozzo, M. and Consoli, D. (2014) Knowledge systematisation, reconfiguration and the organisation of firms and industry: the case of design, Research Policy (forthcoming)

\section{Figure 1: Technological and institutional changes within the home furnishing industry}

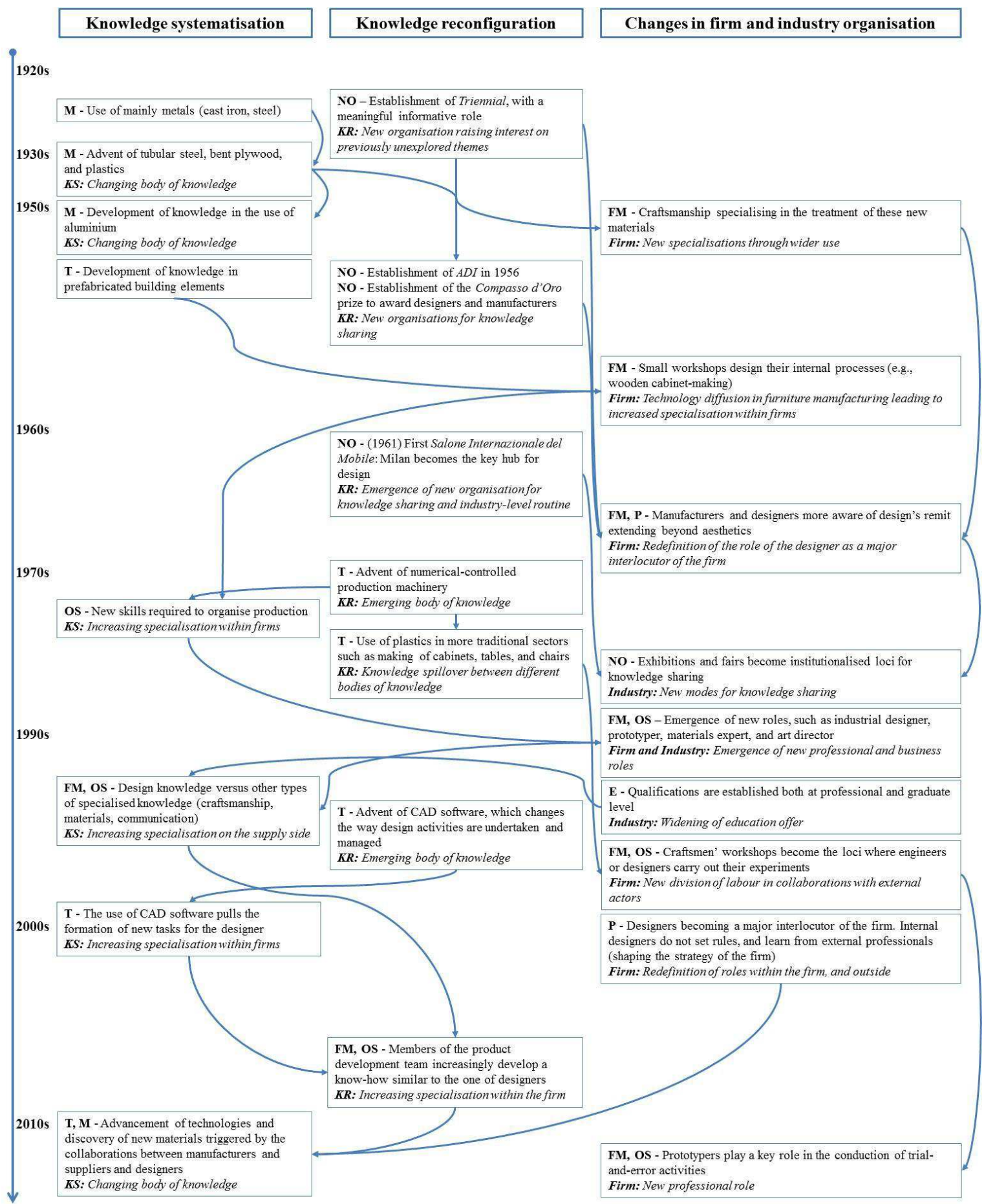




\section{Appendix Table 1: List of informants from RAI Radiotelevisione Italiana S.p.A. (secondary interview data) ${ }^{19}$}

\begin{tabular}{|c|c|c|}
\hline Informant $^{20}$ & Affiliation & Relevance for the Italian design \\
\hline 1. Albricci, Alberto & $\begin{array}{l}\text { Entrepreneur } \\
\text { (economics graduate) }\end{array}$ & $\begin{array}{l}\text { Among the patrons of Italian design, he was invited by Ernesto Gismondi to manage Memphis, a design-focused research laboratory } \\
\text { constituting one of the most prominent exhibitions in home furnishing. }\end{array}$ \\
\hline $\begin{array}{l}\text { 2. Alessi, Alberto } \\
\text { (1946-) }\end{array}$ & $\begin{array}{l}\text { Entrepreneur } \\
\text { (law graduate) }\end{array}$ & $\begin{array}{l}\text { Partner and CEO of his family's business, Alessi. Remembered for the radical innovations introduced, such as the use of metal in } \\
\text { kitchenware (e.g., Espresso kettle, designed by Richard Sapper). }\end{array}$ \\
\hline 3. Amadori, Carlo & $\begin{array}{l}\text { Architect } \\
\text { (architecture graduate) }\end{array}$ & $\begin{array}{l}\text { Founding partner of Studio Immagini Alternative (Studio for Alternative Images). General manager and co-founder (since 1986) of } \\
\text { the event Abitare il tempo, innovative because it reunited manufacturers from different sectors. }\end{array}$ \\
\hline $\begin{array}{l}\text { 4. Baleri, Enrico } \\
(1942-)\end{array}$ & $\begin{array}{l}\text { Architect/Designer and } \\
\text { entrepreneur } \\
\text { (architecture graduate) }\end{array}$ & $\begin{array}{l}\text { Invited by Dino Gavina, Baleri opens a centre for furniture. In } 1968 \text { he founds the research group CES, and collaborates with } \\
\text { important designers and produces objects for Gavina, Flos, and Knoll Intenational. Finally, he founds Baleri Italia (1984) and } \\
\text { Baleri Associati (1986). }\end{array}$ \\
\hline $\begin{array}{l}\text { 5. Baroni, Daniele } \\
(1935-)\end{array}$ & Architect & $\begin{array}{l}\text { Regularly involved with developing various design-related themes (e.g., history, design as a project), he is now part-time Professor } \\
\text { of Architecture at Polytechnic of Milan. He has published design books and contributes to various architecture magazines. }\end{array}$ \\
\hline $\begin{array}{l}\text { 6. Bellini, Mario } \\
(1935-)\end{array}$ & $\begin{array}{l}\text { Architect/Designer } \\
\text { (architecture graduate) }\end{array}$ & $\begin{array}{l}\text { He covered different roles: President of ADI (1969-71); director of Domus Magazine; design director of Olivetti. Awarded four } \\
\text { Compasso d'Oro; twenty-five of his projects are exhibited in the Museum of Modern Art (MoMA). He collaborated with Gruppo } \\
\text { La Rinascente, B\&B, Cassina, Artemide, and Flos. }\end{array}$ \\
\hline $\begin{array}{l}\text { 7. Branzi, Andrea } \\
(1938-)\end{array}$ & $\begin{array}{l}\text { Architect/Designer } \\
\text { (architecture graduate) }\end{array}$ & $\begin{array}{l}\text { Well known as a design critic, he is among the protagonists of the radical modern design through exhibitions and founding member } \\
\text { of the Archizoom Association (with Alberto Branzi, Gilberto Corretti, Paolo Deganello and Massimo Morozzi) and Domus } \\
\text { Academy. Awarded a Compasso d'Oro in 1987. Designer for Alessi, Cassina, Vitra and Zanotta. }\end{array}$ \\
\hline $\begin{array}{l}\text { 8. Busnelli, Piero } \\
\text { (1921-) }\end{array}$ & Founder of $B \& B$ & $\begin{array}{l}\text { Successful entrepreneur, his company attracted well-known designers, such as Des Pas, D'Urbino, Lomazzi, Castiglioni, Mario } \\
\text { Bellini and Richard Sapper. Awarded the Compasso d'Oro on many occasions, one in recognition of his career (1989). }\end{array}$ \\
\hline $\begin{array}{l}\text { 9. Castelli, Giulio } \\
(1920-)\end{array}$ & Founder of Kartell & $\begin{array}{l}\text { Among the members of the committee promoting the foundation of ADI, his company is known worldwide for manufacturing } \\
\text { furniture objects in plastics and attracted well-known designers such as the Castiglioni Brothers, Gae Aulenti, Joe Colombo, Marco } \\
\text { Zanuso and Richard Sapper. }\end{array}$ \\
\hline $\begin{array}{l}\text { 10. Castiglioni, Achille } \\
(1955-)\end{array}$ & Architect/Designer & He is the author of many product successes, with a focus on light systems, chairs, tables, and desks. \\
\hline
\end{tabular}

${ }^{19}$ Interview data publicly available on the Italian state owned public service broadcaster, RAI Radiotelevisione Italiana S.p.A. (source: www.educational.rai.it, first access date: $17 / 12 / 2009)$.

${ }^{20}$ Dates of birth and/or death of the interviewees are included in brackets (where missing, it means that the information was not available). This detail provides additional insight on the timing of the establishment of design as a professional practice. 


\section{Appendix Table 1 (continued)}

\begin{tabular}{|c|c|c|}
\hline Informant & Affiliation & Relevance for the Italian design \\
\hline $\begin{array}{l}\text { 11. Cibic, Aldo } \\
(1955-)\end{array}$ & $\begin{array}{l}\text { Architect/Designer } \\
\text { (architecture graduate) }\end{array}$ & $\begin{array}{l}\text { Founding member of Sottsass Associati (with Ettore Sottsass, Marco Zanini, and Matteo Thun). He contributes actively to the } \\
\text { management of Memphis and teaches at Domus Academy. }\end{array}$ \\
\hline 12. Colombari, Rossella & Art dealer and collector & Known as the expert of the design produced by Carlo Mollino, she has organised series of events around his work. \\
\hline $\begin{array}{l}\text { 13. Colombo, Joe } \\
(1914-1978)\end{array}$ & $\begin{array}{l}\text { Architect/Designer and } \\
\text { entrepreneur } \\
\text { (architecture graduate) }\end{array}$ & $\begin{array}{l}\text { Well-known designer who collaborated with Luigi Fontana and Sebastian Matta, he joined the Movimento di Arte Concreta } \\
\text { (Movement of Applied Art). He designed renowned products such as Universal chair (one of Kartell's best sellers), Ragno light } \\
\text { (awarded a Compasso d'Oro) and O-Luce lamp. }\end{array}$ \\
\hline $\begin{array}{l}\text { 14. De Lucchi, Michele } \\
\text { (1951-) }\end{array}$ & $\begin{array}{l}\text { Architect and designer } \\
\text { (architecture graduate) }\end{array}$ & $\begin{array}{l}\text { Co-founder of the artistic group Cavart, he designed different products for Alchimia and Memphis. He collaborates with different } \\
\text { firms such as Acerbis, Artemide, Arflex, Biefeplast, Moroso, and Vitra. Awarded a Compasso d'Oro in } 1989 .\end{array}$ \\
\hline $\begin{array}{l}\text { 15. Gavina, Dino } \\
(1922-2007)\end{array}$ & Entrepreneur & $\begin{array}{l}\text { Founder of the eponymous company, he was active in reproducing famous collector's items. His career started with Flos, where he } \\
\text { worked on light systems, and continued with Simon International, where he explored the serial and modular production techniques. }\end{array}$ \\
\hline $\begin{array}{l}\text { 16. Giovannoni, Stefano } \\
(1954-)\end{array}$ & $\begin{array}{l}\text { Architect/Designer } \\
\text { (architecture graduate) }\end{array}$ & $\begin{array}{l}\text { Academic and designer, he is known for his collaboration with G. Venturini in the King Kong experience (focusing on design as a } \\
\text { means of communication) and Alessi. }\end{array}$ \\
\hline $\begin{array}{l}\text { 17. Gismondi, Ernesto } \\
(1931-)\end{array}$ & $\begin{array}{l}\text { Entrepreneur and designer } \\
\text { (engineering graduate) }\end{array}$ & $\begin{array}{l}\text { Founder of Artemide, known worldwide for having revolutionised the residential illumination sector. Co-founder of Memphis, a } \\
\text { laboratory where he and his team conducted their experiments. He has also held administrative roles within ADI and Triennial. }\end{array}$ \\
\hline $\begin{array}{l}\text { 18. Magistretti, Vico } \\
(1920-2006)\end{array}$ & Architect/Designer & $\begin{array}{l}\text { His talent has been recognised worldwide through different prizes (Compasso d'Oro, Triennial's Golden Medal) and exhibitions to } \\
\text { his honour. He collaborated with firms such as Acerbis, Artemide, Cassina, Flou, Kartell and O-Luce. }\end{array}$ \\
\hline 19. Mari, Enzo & Artist/Designer & $\begin{array}{l}\text { He co-organised many important events, such as the Biennale in Zagreb, the Triennials in Milan and the Biennales in Venice. He } \\
\text { has collaborated with a wide range of companies. }\end{array}$ \\
\hline 20. Marzani, Stefano & Architect/Designer & Design manager for Philips. His objects were presented in a special exhibition at the Salone Internazionale del Mobile 1999. \\
\hline $\begin{array}{l}\text { 21. Mendini, Alessandro } \\
(1931-)\end{array}$ & $\begin{array}{l}\text { Architect/Designer } \\
\text { (architecture graduate) }\end{array}$ & $\begin{array}{l}\text { He has worked as an architect, designer and journalist for many years. At a certain point in his career, he starts developing an } \\
\text { intellectual debate around the world of design and founds and directs the magazines Casabella, Modo and Domus. }\end{array}$ \\
\hline $\begin{array}{l}\text { 22. Mollino, Carlo } \\
(1905-1973)\end{array}$ & $\begin{array}{l}\text { Photograph, graphic } \\
\text { engineer, set designer }\end{array}$ & $\begin{array}{l}\text { He is defined as the 'Designer without the industry'. Critics believe he developed his talent for design through the wide range of } \\
\text { professional activities he undertook. His furniture production incorporated many innovations in terms of production techniques and } \\
\text { materials (e.g., cold bending plywood). }\end{array}$ \\
\hline $\begin{array}{l}\text { 23. Morello, Augusto } \\
(1928-)\end{array}$ & $\begin{array}{l}\text { Art dealer (chemical } \\
\text { engineering graduate) }\end{array}$ & $\begin{array}{l}\text { General director of Olivetti and La Rinascente, he has actively promoted the Italian design. He has directed the Compasso d'Oro } \\
\text { and is among the founders of ADI. He was also an academic at the Faculty of Architecture (Polytechnic of Milan). }\end{array}$ \\
\hline $\begin{array}{l}\text { 24. Noorda, Bob } \\
(1927-2010)\end{array}$ & $\begin{array}{l}\text { Designer (industrial } \\
\text { design graduate) }\end{array}$ & $\begin{array}{l}\text { Of Dutch origins, he moved to Italy in the 1960s and participated actively to the developments in graphics. Designer of the tube } \\
\text { underground signposting in Milan (Compasso d'Oro award) and other cities. He collaborated with Pirelli and La Rinascente. }\end{array}$ \\
\hline $\begin{array}{l}\text { 25. Pesce, Gaetano } \\
(1939-)\end{array}$ & $\begin{array}{l}\text { Architect/Designer } \\
\text { (architecture graduate) }\end{array}$ & $\begin{array}{l}\text { Founder of the } N \text { Group, and protagonist of many international intercultural events and movements. Among the founders of } \\
\text { Bracciodiferro, set up to produce experimental objects, and contributors to MoMA's "Italy: the new domestic landscape". }\end{array}$ \\
\hline
\end{tabular}




\section{Appendix Table 1 (continued)}

\begin{tabular}{|c|c|c|}
\hline Informant & Affiliation & Relevance for the Italian design \\
\hline $\begin{array}{l}\text { 26. Pininfarina, Sergio } \\
(1926-)\end{array}$ & $\begin{array}{l}\text { Entrepreneur } \\
\text { (aeronautical engineering } \\
\text { graduate) }\end{array}$ & $\begin{array}{l}\text { President of the eponymous company founded by his father. With the support of Alberto Morelli, Pininfarina undertakes his } \\
\text { studies and develops a series of products with success from the post-war period onwards. He collaborates with Ferrari, Alfa } \\
\text { Romeo, Lancia and Peugeot. }\end{array}$ \\
\hline $\begin{array}{l}\text { 27. Ponti, Gio } \\
(1891-1979)\end{array}$ & Architect/Designer & $\begin{array}{l}\text { He was a designer (Fontana Arte, Cassina), an architect (Pirelli skyscraper in Milan), a promoter of the Italian design (Triennials, } \\
\text { Biennales, Compasso d'Oro, ADI), and an intellectual (author of influential books, and lecturer at the Faculty of Architecture in } \\
\text { Milan). }\end{array}$ \\
\hline 28. Santachiara, Denis & Designer/Artist & $\begin{array}{l}\text { Self-taught expert of designer, he starts off his career in the automobile industry and, since 1975, he tackles themes of neo-design. } \\
\text { He collaborates with many firms such as Luceplan, Artemide, Vitra, Campeggi and Magis. He has been awarded different prizes } \\
\text { (e.g., Design World 2000). }\end{array}$ \\
\hline $\begin{array}{l}\text { 29. Sapper, Richard } \\
(1932-)\end{array}$ & $\begin{array}{l}\text { Designer/Graphic } \\
\text { (economics graduate) }\end{array}$ & $\begin{array}{l}\text { He started his career at Mercedes; he then moves to Italy and collaborates with designers such as Gio Ponti, Alberto Rosselli and } \\
\text { Marco Zanuso. After some consultancy, he becomes the world product design manager of IBM. He has been awarded ten } \\
\text { Compasso d'Oro and many of his objects are exhibited at the MoMA. }\end{array}$ \\
\hline $\begin{array}{l}\text { 30. Sarfatti, Riccardo } \\
(1940-2010)\end{array}$ & $\begin{array}{l}\text { Architect } \\
\text { (architecture graduate) }\end{array}$ & $\begin{array}{l}\text { Academic at the Faculty of Architecture and Design in Milan and Venice. Founder of Luceplan with Paolo Rizzato and Sandra } \\
\text { Severi, he is the first to apply the LED technology to lighting systems. }\end{array}$ \\
\hline $\begin{array}{l}\text { 31. Sottsass, Ettore } \\
(1917-2007)\end{array}$ & $\begin{array}{l}\text { Architect/Designer } \\
\text { (architecture graduate) }\end{array}$ & $\begin{array}{l}\text { Director of the Computer business unit in Olivetti and awarded a Compasso d'Oro. He contributed to the coordination of many } \\
\text { Triennials (Milan) and Biennales (Venice). He is co-founder of Memphis, active promoter of the Global Tools movement, and } \\
\text { founder of Studio Sottsass Associati in 1980. }\end{array}$ \\
\hline 32. Terragni, Emilio & Architect & $\begin{array}{l}\text { Among the pioneers of the modern movement in Italy, his activity can be featured by the continuous search (architecture graduate) } \\
\text { for new and innovative materials, either in architecture or building construction. }\end{array}$ \\
\hline $\begin{array}{l}\text { 33. Thun, Matteo } \\
\text { (1952-) }\end{array}$ & $\begin{array}{l}\text { Architect/Designer } \\
\text { (architecture graduate) }\end{array}$ & $\begin{array}{l}\text { Co-founder of Studio Sottsass Associati and Memphis, he collaborated with Alessi, Tiffany, Campari and Swatch. He has been } \\
\text { awarded three Compasso d'Oro. }\end{array}$ \\
\hline $\begin{array}{l}\text { 34. Valle, Gino } \\
(1923-2003)\end{array}$ & Architect/Designer & $\begin{array}{l}\text { Trainee of Carlo Scarpa and Giuseppe Samonà, he started his career in his father's company (Valle, in Udine), he collaborated with } \\
\text { with Solari (awarded three Compasso d'Oro) and Zanussi. He also taught at the University of Venice. }\end{array}$ \\
\hline 35. Wilson, Bob & Artist and set designer & $\begin{array}{l}\text { Not originally from Italy or based in Italy, he has acted as a critic of the evolution of design in Italy. One of the highlights of his } \\
\text { career has been to organise and coordinate the Seventies angels event for celebrating the 70th birthday of Domus Magazine. }\end{array}$ \\
\hline $\begin{array}{l}\text { 36. Zanuso, Marco } \\
(1916-2001)\end{array}$ & $\begin{array}{l}\text { Architect/Designer } \\
\text { (architecture graduate) }\end{array}$ & $\begin{array}{l}\text { Architect and urban designer, he was co-director of Domus Magazine, copy editor of the magazine Casabella, an lecturer at the } \\
\text { Faculty of Architecture (Polytechnic of Milan). He was honoured three times at the Triennials and five times at the Compasso } \\
\text { d'Oro. }\end{array}$ \\
\hline $\begin{array}{l}\text { 37. Zorzi, Renzo } \\
(1921-2010)\end{array}$ & $\begin{array}{l}\text { Intellectual and } \\
\text { copy editor }\end{array}$ & $\begin{array}{l}\text { He was the copy editor of the national paper L'Arena. He was called by Olivetti to coordinate the cultural activities of the firm, } \\
\text { and when its CEO died, Zorzi became the firm's art director. }\end{array}$ \\
\hline
\end{tabular}




\section{Appendix Table 2: List of informants from sampled home furnishing firms (primary interview data)}

\begin{tabular}{|c|c|c|c|c|}
\hline Firm (no. interviews) & Date & Informant & Description & Length \\
\hline Aran World (1) & $16 / 04 / 2010$ & $\begin{array}{l}\text { Marketing Director, also } \\
\text { member of the Board }\end{array}$ & $\begin{array}{l}\text { Face-to-face, Milan (during the Salone } \\
\text { Internazionale del Mobile 2010) }\end{array}$ & $40 \mathrm{~min}$ \\
\hline Boffi (1) & 20/05/2010 & Marketing Director & Face-to-face, Milan (firm's showroom) & $71 \mathrm{~min}$ \\
\hline Citterio (1) & 05/05/2010 & Art Director & Email & $\mathrm{n} / \mathrm{a}$ \\
\hline Dieffebi (1) & $11 / 05 / 2010$ & Marketing Director & Face-to-face, Treviso (firm’s site) & $60 \mathrm{~min}$ \\
\hline Edra (1) & 08/05/2010 & Art Director & Face-to-face, Milan (art director's studio) & $50 \mathrm{~min}$ \\
\hline Lago (1) & $14 / 05 / 2010$ & Marketing Director & Face-to-face, Milan (firm’s showroom) & $95 \min$ \\
\hline Luceplan (1) & $18 / 05 / 2010$ & $\begin{array}{l}\text { President (Co-founder), also } \\
\text { internal designer }\end{array}$ & Face-to-face, Milan (firm’s site) & $65 \min$ \\
\hline Magis (1) & $10 / 05 / 2010$ & President (Founder) & Face-to-face, Treviso (firm’s site) & $80 \mathrm{~min}$ \\
\hline Molteni\&C (1) & 06/05/2010 & Marketing Director & Face-to-face, Milan (firm’s site) & $45 \min$ \\
\hline Mussi (1) & $30 / 04 / 2010$ & Art Director & Face-to-face, Milan (art director's studio) & $60 \mathrm{~min}$ \\
\hline Ozzio Design (1) & $16 / 04 / 2010$ & Marketing Director & $\begin{array}{l}\text { Face-to-face, Milan (during the Salone } \\
\text { Internazionale del Mobile 2010) }\end{array}$ & $30 \mathrm{~min}$ \\
\hline Presotto Industrie (1) & $13 / 05 / 2010$ & R\&D and Marketing director & Face-to-face, Pordenone (firm's site) & $56 \min$ \\
\hline SMA (1) & 04/05/2010 & President (Co-founder) & Face-to-face & $50 \mathrm{~min}$ \\
\hline $\begin{array}{l}\text { Valcucine (1) } \\
\text { (14 interviews in total) }\end{array}$ & $11 / 05 / 2010$ & $\begin{array}{l}\text { President (Co-founder), also } \\
\text { the firm's Art Director }\end{array}$ & Face-to-face, Pordenone (firm's site) & $55 \min$ \\
\hline
\end{tabular}




\section{Appendix Table 3: Set of categories used to classify the events leading to emergence of design as a business activity or function}

\begin{tabular}{|c|c|c|}
\hline \multicolumn{3}{|c|}{ PRELIMINARY SET OF CATEGORIES } \\
\hline $\begin{array}{l}\text { Changes in the education } \\
\text { qualifications (E) }\end{array}$ & $\begin{array}{l}\text { Vincenti (1990), } \\
\text { Vona and Consoli (2011) }\end{array}$ & $\begin{array}{l}\text { "There is a subsidiary of the University of Trieste here in Pordenone, which has been specifically established to } \\
\text { accommodate those students coming from the Professional High-School for the treatment of wood. The city hall has become } \\
\text { a key sponsor of this institution and we are also part of the committee that supports these kinds of initiatives. For instance, } \\
\text { our Public Relations Director is a lecturer at the university." (Presotto Industrie) } \\
\text { "... and this should be the role of the designer, to characterise, through the aesthetics, the product with a set of values that } \\
\text { [...] adds to the engineered product and complete it." (Luceplan) }\end{array}$ \\
\hline $\begin{array}{l}\text { Emergence of new types of } \\
\text { business functions or changes in } \\
\text { firm organisation (NO) }\end{array}$ & Rosenberg (1963) & $\begin{array}{l}\text { "There have been changes in the types of required competencies, but even more with regard to the dynamics of } \\
\text { collaborations... towards the end of the 20th century there used to be regular collaborations with craftsmen. Over time, } \\
\text { we have tried to incorporate this knowledge through internal development of their expertise..." (Citterio) } \\
\text { "I tend to mistrust external designers, we collaborate with very few designers, the reason being that to make a good } \\
\text { product there needs to be a designer and the firm willing to do design, and this is beyond the relationship with the designer } \\
\text { or where (s)he is located. There needs to be a continuity between the evolution of the project realised by the designer and } \\
\text { the evolution (and the experimentation) of the prototype, these moments should be highly connected." (Luceplan) }\end{array}$ \\
\hline $\begin{array}{l}\text { Emergence of new practical } \\
\text { know-how and professional } \\
\text { roles }(\mathrm{P})\end{array}$ & Rosenberg (1998a) & $\begin{array}{l}\text { "It is very common that recently graduates submit their CVs and they think that they are the best designers ever, 'I am a } \\
\text { designer, hence I am a Michelangelo'. Solid experience is needed and very often young graduates lack this, just } \\
\text { collaborating with a designer, and understanding what products a company manufactures, this is already key to } \\
\text { understanding that a product is designed to be sold. These designers need to understand about and become familiar with } \\
\text { the companies they work with as well as the market. This is extremely important." (Dieffebi) } \\
\text { "Our employees are very young, in the sense that we have recruited } 10 \text { designers, all under } 35 \text { [...] It is always about } \\
\text { compromises, because the designer needs to be different from the sales person, and so has a creative role, whilst the sales } \\
\text { person has to be more realistic, thus, the two roles interact, and somehow new, successful products are created." (Aran } \\
\text { World) }\end{array}$ \\
\hline ADDED SET OF CATEGO & & \\
\hline Source of learning & Theoretical justification & Empirical justification \\
\hline Change of technologies $(\mathrm{T})$ & Rosenberg (1963) & $\begin{array}{l}\text { "The research in new technologies is highly diversified across sectors, so too is the role of craftsmen, for instance, in the } \\
\text { wooden furniture sector, even those pieces with traditional shapes, which fall in the cabinet-making tradition, are } \\
\text { nowadays manufactured by numerically controlled machines, and the artisans deal mainly with the finishing touches..." } \\
\text { (Baroni Daniele) } \\
\text { "Even the use of paper in lamp manufacturing, for instance, like this one that has been produced by Design Gallery, is not } \\
\text { part of the Western tradition, because from a certain point in time onwards, it has tried to prioritise reliability and } \\
\text { functionality... whilst the paper is characterised by a more fragile identity, it is more delicate. The light passes through a } \\
\text { series of disconnected filters, creating a special type of warmth around the lamp. And this is one of the elements that I have } \\
\text { seen become widespread in contemporary industrial production." (Branzi Andrea) }\end{array}$ \\
\hline
\end{tabular}




\section{Appendix Table 3 (continued)}

\begin{tabular}{|c|c|c|}
\hline Source of learning & Theoretical justification & Empirical justification \\
\hline Change of materials (M) & Walsh (1996) & $\begin{array}{l}\text { "We are currently carrying out different types of research regarding materials. One that is particularly satisfying is the } \\
\text { research in fabrics... it is a fabric that is highly stain- and tear-resistant. We are on the right path, but we have to move } \\
\text { forward." (Busnelli Piero) } \\
\text { "Let's say that in the 1940-50s wood manufacturing was much simpler. Just at the end of the Second World War, research } \\
\text { was still at its early stage, a lot was yet to be discovered. Carlo Mollino somehow felt the need to conduct research on new } \\
\text { materials, it is back then that the industry in Brianza took off and, although his production mainly features wooden } \\
\text { furniture, he has played a key role in fostering experimentation in the surrounding area." (Colombari Rossella) }\end{array}$ \\
\hline $\begin{array}{l}\text { Transformation in the activities } \\
\text { carried out by furniture } \\
\text { manufacturers (FM) }\end{array}$ & $\begin{array}{l}\text { Rosenberg (1963), } \\
\text { Miozzo and Grimshaw } \\
(2011)\end{array}$ & $\begin{array}{l}\text { "I'm afraid we are obliged to collaborate with craftsmen, we constantly look for craftsmen. I am happy about this. [...] } \\
\text { When we are developing a wooden door, I need to be assisted by the laboratory of a craftsman, because I [the firm] am not } \\
\text { organised internally to do it, or if you think of steel, or stone, a bath made with stone, I would search for and select the best } \\
\text { craftsman, who could manufacture the bath from one piece of stone." (Boffi) } \\
\text { "Something that characterises us is this ability to use very advanced technologies in combination with manual ability, and } \\
\text { thus... a significant component of our manufacturing is artisanal, and being capable of coordinating resources, available } \\
\text { internally and externally, is key for our success." (Edra) }\end{array}$ \\
\hline $\begin{array}{l}\text { Transformation in the activities } \\
\text { carried out by sectors } \\
\text { different from furniture (OS) }\end{array}$ & Rosenberg $(1998 \mathrm{a}, \mathrm{b})$ & $\begin{array}{l}\text { "Sometimes it is curiosity, sometimes the structure, or the same suppliers that propose innovative materials to us... } \\
\text { sometimes thanks to our informal network of relationships, sometimes because we proactively participate in events not } \\
\text { necessarily connected with the furniture sector, for instance materials fairs in Germany or France, and looked for new } \\
\text { collaborations." (Molteni\&C) } \\
\text { "Until now we made the prototypes, now we ask our suppliers to realise the prototype, somehow we oblige them, because } \\
\text { the suppliers with their team of craftsmen or prototypers are the ones to spot problems, and solve them, and by being able } \\
\text { to master this problem-solving, it will be easier for us to move forward in the product development process." (Presotto } \\
\text { Industrie) }\end{array}$ \\
\hline
\end{tabular}


D'Ippolito, B., Miozzo, M. and Consoli, D. (2014) Knowledge systematisation, reconfiguration and the organisation of firms and industry: the case of design, Research Policy (forthcoming)

\section{Appendix Exhibit 1: Interview guide}

\section{About NPD (and design) process}

- What are the roots of your design traditions?

- Has your company undergone any radical change over the last 10-15 years? Has design played a specific role throughout? If so, when and how did the transition towards a design-intensive firm start?

- Could you please describe the processes of coordinating human resources (e.g., developing new skills / competencies, buying-in specialised expertise)?

- How is product testing managed and coordinated? What actions are taken to avoid a project reaching the prototype stage and not being approved for production (i.e., which parameters / indicators do you rely on to reduce a project's risk of failure)?

- What parameters do you use to establish whether a certain design is ready for being industrialised? Usually briefs include an ambiguous group of desired properties for this object: which parameters guide you throughout the prototyping phase?

- What is the nature, frequency and object of interaction with suppliers / other manufacturers / sector-specific institutions?

\section{About skills and competencies}

- Which design competencies were already present in-house? Were there any that the top management wanted to acquire?

- Which other competencies were being developed in-house, and which ones do you think are still missing?

- How are design activities organised (e.g., in-house team, collaborations with external designers, or combination of both)?

\section{About creativity}

- How would you describe the boundary between aesthetics and functionality in your production? Which parameters define this process in terms of skills, competencies, technologies, or other elements?

\section{About project work}

- What does your role involve in the context of the product development process?

- How would you describe the tasks that are assigned to you? What input do you receive, and by whom?

- What are the interactions between you/your team and other departments, external designers, else, throughout the project?

- Is there any feedback you receive? Where does it come from? Are there any sharing mechanisms in place? If so, how do they work? 